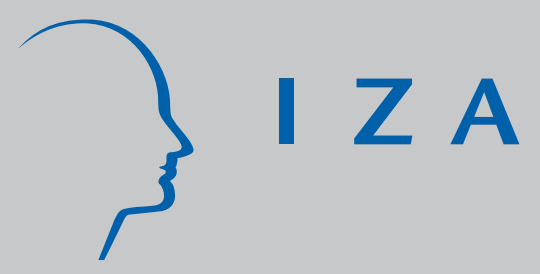

IZA DP No. 2903

How Does Financial Gobalization Affect Risk Sharing?

Patterns and Channels

M. Ayhan Kose

Eswar S. Prasad

Marco E. Terrones

July 2007 


\title{
How Does Financial Globalization Affect Risk Sharing? Patterns and Channels
}

\author{
M. Ayhan Kose \\ International Monetary Fund
}

Eswar S. Prasad

Cornell University and IZA

Marco E. Terrones

International Monetary Fund

\section{Discussion Paper No. 2903 \\ July 2007}

IZA

P.O. Box 7240

53072 Bonn

Germany

Phone: +49-228-3894-0

Fax: +49-228-3894-180

E-mail: iza@iza.org

Any opinions expressed here are those of the author(s) and not those of the institute. Research disseminated by IZA may include views on policy, but the institute itself takes no institutional policy positions.

The Institute for the Study of Labor (IZA) in Bonn is a local and virtual international research center and a place of communication between science, politics and business. IZA is an independent nonprofit company supported by Deutsche Post World Net. The center is associated with the University of Bonn and offers a stimulating research environment through its research networks, research support, and visitors and doctoral programs. IZA engages in (i) original and internationally competitive research in all fields of labor economics, (ii) development of policy concepts, and (iii) dissemination of research results and concepts to the interested public.

IZA Discussion Papers often represent preliminary work and are circulated to encourage discussion. Citation of such a paper should account for its provisional character. A revised version may be available directly from the author. 


\section{ABSTRACT}

\section{How Does Financial Globalization Affect Risk Sharing? Patterns and Channels ${ }^{*}$}

In theory, one of the main benefits of financial globalization is that it should allow for more efficient international risk sharing. In this paper, we provide a comprehensive empirical evaluation of the patterns of risk sharing among different groups of countries and examine how international financial integration has affected the evolution of risk sharing patterns. Using a variety of empirical techniques, we conclude that there is at best a modest degree of international risk sharing, and certainly nowhere near the levels predicted by theory. In addition, only industrial countries have attained better risk sharing outcomes during the recent period of globalization. Developing countries have, by and large, been shut out of this benefit. The most interesting result is that even emerging market economies, which have witnessed large increases in cross-border capital flows, have seen little change in their ability to share risk. We find that the composition of flows may help explain why emerging markets have not been able to realize this presumed benefit of financial globalization. In particular, our results suggest that portfolio debt, which has dominated the external liability stocks of most emerging markets until recently, is not conducive to risk sharing.

JEL Classification: F2, F4

Keywords: international financial integration, risk sharing, cross-country correlations of consumption and output, composition of capital flows

Corresponding author:

Eswar S. Prasad

Department of Applied Economics and Management

Cornell University

440 Warren Hall

Ithaca, NY 14853

USA

E-mail: eswar.prasad@cornell.edu

\footnotetext{
* Earlier versions of this paper were presented at the 2006 IMF Annual Research Conference, the January 2007 AEA meetings, and the 2007 IMF-Cornell conference on Financial Globalization. We are grateful to our discussants, Jonathan Heathcote and Bent Sorenson, for their helpful suggestions. We also thank Karen Lewis, Enrique Mendoza, Fabrizio Perri and conference participants for helpful comments. Dionysios Kaltis provided able research assistance. The views expressed in this paper are those of the authors and do not necessarily reflect the views of the IMF or IMF policy.
} 


\section{Introduction}

In theory, one of the main benefits of financial globalization is that it provides increased opportunities for countries to smooth consumption growth in the face of countryspecific fluctuations in income growth. With well-developed domestic financial markets, economic agents within a country can share risk amongst themselves. However, insuring against country-wide shocks requires openness to financial flows that would allow agents in different countries to pool their risks efficiently. Thus, financial globalization should generate welfare gains by reducing the volatility of aggregate consumption and also by delinking national consumption and income (see Kose, Prasad, Rogoff, and Wei, 2006).

There is a substantial literature examining patterns of risk sharing among advanced industrial economies (some of the notable contributions include Obstfeld, 1994, 1995; Lewis, 1996, 1997; Sorenson and Yosha, 1998). The main conclusion of this literature is that the degree of risk sharing is rather limited even among advanced industrial economies, leaving a considerable amount of potential welfare gains unexploited. Recent work examining the evolution of risk sharing among these economies presents conflicting results. While some studies suggest that it has increased during the recent period of globalization (e.g., Sorensen, Yosha, Wu and Shu, 2006; Artis and Hoffman, 2006a, 2006b; Giannone and Reichlin, 2006), others have found little evidence of better risk sharing among industrial economies (see Moser, Pointner, and Scharler, 2004; Bai and Zhang, 2005).

The literature on risk sharing patterns for non-industrial economies is relatively sparse. Obstfeld (1994) and Lewis (1997) do include some of these countries in their analysis, but their samples (which end in 1988 and 1992, respectively) do not cover much of the recent wave of financial globalization that enveloped the emerging market economies starting in the mid-1980s. Given the relatively higher volatility of consumption fluctuations in these economies, and the higher potential welfare gains of stabilizing these fluctuations, understanding these economies' risk sharing patterns is clearly of considerable interest. ${ }^{1}$

The objective of this paper is to study the impact of financial globalization on the degree of international consumption risk sharing for a large set of industrial and developing countries. In particular, we make three contributions to the empirical literature on

\footnotetext{
${ }^{1}$ Quantitative estimates suggest that the potential welfare gains for developing countries can be very large (Prasad, Kose, Rogoff and Wei, 2003; and Imbs and Mauro, 2007).
} 
international risk sharing. First, we extend the analysis to a large group of emerging markets and other developing economies, and investigate the extent of risk sharing in these economies in a unified framework. Second, we examine changes over time in the degree of risk sharing across different groups of countries and attempt to relate those changes to increased financial flows and other factors, including country characteristics. Third, we provide a careful evaluation of alternative measures of risk sharing, drawn from different empirical approaches. In principle, many of these approaches are equivalent, but there are subtle differences that affect the results. Thus, our comprehensive evaluation of risk sharing patterns based on a range of measures provides a benchmark set of results that should be useful for further theoretical and empirical work in this area.

Our main conclusion is that, notwithstanding the prediction of conventional theoretical models that financial globalization should foster increased risk sharing across all countries, there is no evidence that this is true for developing countries. Even for the group of emerging market economies - which have become far more integrated into global markets than other developing countries - financial globalization has not improved the degree of risk sharing. For advanced industrial economies, there is indeed some evidence that risk sharing has improved in the last decade and a half. Our formal econometric analysis confirms that increased financial openness improves risk sharing among industrial economies, but this effect is absent for the other two groups of countries.

Why are non-industrial countries unable to share risk more efficiently despite their increasing integration into global financial markets? One possibility is that these countries rely largely on less stable capital such as bank loans and other forms of debt that may not allow for efficient risk sharing. Indeed, when we break up capital stocks into different categories - FDI, portfolio equity, portfolio debt etc. - we find some evidence that the composition of stocks influences the ability of developing countries to share risk. In particular, external debt appears to hinder the ability of emerging market economies to share their consumption risk.

Another possibility is that the combination of domestic financial liberalization and international financial integration could generate phenomena such as consumption booms that can end badly, especially when they are financed by debt accumulation. The inefficient intermediation of foreign finance by underdeveloped financial systems that exist in many 
developing countries may be another reason. In our empirical work, we attempt to explore the relationship between domestic financial development and financial integration in terms of risk sharing outcomes. We also look at whether other factors such as trade openness and institutional quality systematically affect risk sharing outcomes. None of these factors seems to be a major determinant of differences in the degree of risk sharing outcomes across different groups of countries (or of changes over time within specific groups of countries).

One interpretation of our results is that there is a threshold effect in terms of how financial globalization improves risk sharing, in that only countries that are substantially integrated into global markets (in de facto terms) appear to attain these benefits. Indeed, Kose, Prasad, and Terrones (2003) document that the volatility of consumption growth relative to that of income growth, a crude measure of risk sharing, tends to increase at intermediate levels of financial integration, and then declines at higher levels of integration.

In section II, we present a survey of theoretical arguments linking increased financial integration to improvements in the degree of consumption risk sharing. In section III, we provide a summary of the rich empirical literature on the changes in the patterns of risk sharing in response to rising international financial flows. Next, we discuss the main features of our dataset. This is followed in section V by a set of basic stylized facts concerning the evolution of correlations of output and consumption growth. In section VI, we examine how the degree of risk sharing has changed over time using various regression models. In section VII, we evaluate the direct impact of financial globalization on the degree of risk sharing. In section VIII, we then examine if the composition of flows and certain country characteristics could explain the inability of emerging markets to attain the risk sharing benefits of financial globalization. We conclude with a brief summary of our findings in section IX.

\section{International Consumption Risk Sharing in Theory}

Conventional theoretical models in open economy macroeconomics and international finance yield clear predictions about the impact of financial integration on risk sharing. We first summarize the predictions of theory about the impact of financial integration on the patterns of international consumption and output correlations. Since most of these predictions turn out not to be supported by the data, we then discuss some extensions of the basic models to account for the empirical facts. We also briefly survey theoretical predictions about the 
volatility of consumption since these involve different, but related, approaches to measuring the impact of financial globalization on international risk sharing.

\section{II.1. Theoretical Predictions Regarding Output and Consumption Correlations}

Standard intertemporal open economy models yield predictions about the effects of financial integration on risk sharing, as measured by cross-country correlations of consumption. Dynamic stochastic general equilibrium (DSGE) models, in particular, have been able to generate quantitative predictions along these lines. In the absence of trade in goods and financial assets (the case of autarky), consumption should be perfectly or highly correlated with domestic output, depending on the formulation of the utility function and possibilities for intertemporal smoothing through investment (or storage technologies).

By contrast, with complete markets that enable perfect risk sharing, it should be possible to decouple fluctuations in consumption from those of output, yielding lower correlations between domestic consumption and national output. Predicted cross-country correlations of consumption growth rates would be perfect or very high. Consumption fluctuations would be more correlated across countries than output fluctuations. Moreover, theoretical models with complete markets predict that correlation of consumption growth with the growth of world output (or, equivalently, world consumption) would be higher than that with domestic output. ${ }^{2}$ Contrary to these predictions, the data suggest that cross-country consumption correlations are rather low and, in most cases, are lower than output correlations. Backus, Kehoe, and Kydland (1995) refer to this as "the quantity anomaly".

\footnotetext{
${ }^{2}$ See Backus, Kehoe, and Kydland (1995) and Pakko (1998). If consumption was the only argument in the utility function, the consumption-world output correlation would be unity. If the utility function included other arguments such as leisure, the correlation would be less than one, but would still be very high. Heathcote and Perri (2004) argue that, by introducing certain modifications such as differences in consumption baskets across countries into an otherwise standard model, it is possible to alter the theoretical predictions regarding consumption and output correlations, even with complete markets and efficient international risk sharing. Pakko (2003) notes that the assumption of a sufficiently low elasticity of substitution between domestic and foreign goods could get some predictions of the model closer to the data.
} 


\section{II.2. Explaining Imperfect Risk Sharing in Theory}

As we discuss in the next section, a number of empirical papers test the risk sharing implications of theory and show that they are mostly rejected by data. Some of the leading theoretical explanations for the low degree of risk sharing are as follows.

- Non-tradable and durable goods. Models with non-traded goods, when augmented with large preference shocks, generate low predicted cross-country consumption correlations even with perfect risk sharing (see Stockman and Tesar, 1995). However, the empirical evidence supporting the relevance of large preference shocks in generating business cycles is weak. The lumpiness of durables purchases may also make consumption expenditures more correlated with output even in an environment with risk sharing.

- Market incompleteness. International financial markets are incomplete as it is not possible to buy insurance against all future contingencies. Moreover, one could argue that since it is not yet possible to trade financial instruments linked to a broad measure of national output, it is normal to expect less than perfect consumption correlations across countries. Models with incomplete asset markets have been more successful in generating the rankings of cross-country consumption and output correlations observed in the data, although even these models require some strong assumptions to match certain features of the data (Baxter, 1995, and Heathcote and Perri, 2002).

- Transaction costs. Transaction costs associated with international trade of goods and assets are large, and could reduce the incentives for international risk sharing. Recent models with trade costs--such as transportation costs, tariffs and non-tariff barriers--are able to generate relatively low cross-country output and consumption correlations (see Obstfeld and Rogoff, 2001). Bai and Zhang (2005) argue, however, that trade transactions costs cannot by themselves account for imperfect risk sharing since the risk sharing benefits of financial integration could be realized only if international financial flows are much larger than their current levels. ${ }^{3}$

\footnotetext{
${ }^{3}$ Brandt, Cochrane and Santa-Clara (2006) show that, when the extent of risk sharing is computed using asset market data, the extent of risk sharing is quite high between some pairs of G-7 countries.
} 


\section{II.3. Theoretical Predictions Regarding Consumption Volatility}

Theory suggests that financial integration should reduce the volatility of consumption (relative to that of output or income). In particular, if output fluctuations are not perfectly correlated across countries, it is possible to show that trade in financial assets can be used to delink national consumption levels from the country-specific components of output fluctuations in a DSGE model with complete markets, which should make consumption growth less volatile relative to income growth. From a time series perspective, increasing financial integration should lead to declining relative volatility of consumption growth.

Contrary to these predictions, Kose, Prasad and Terrones (2003) document that the volatility of consumption growth relative to that of income growth increased for emerging market economies in the 1990 s, even as these countries were becoming more financially integrated. Interestingly, increasing financial openness is associated with rising relative volatility of consumption only up to a threshold. Beyond a certain level of financial integration, an increase in integration reduces the relative volatility of consumption. In other words, the benefits of financial integration in terms of improved risk sharing and consumption smoothing possibilities appear to accrue only beyond a threshold level of financial integration - the evidence suggests that it is almost entirely just industrial countries that are beyond this threshold level of integration.

A number of recent theoretical papers have attempted to explain the positive association between financial integration and the relative volatility of consumption growth. For instance, Levchenko (2005) and Leblebicioglu (2006) construct dynamic general equilibrium models where only some agents have access to international financial markets. In both models, financial integration leads to an increase in the volatility of aggregate consumption since agents with access to international financial markets stop participating in risk sharing arrangements with those who do not have such access.

\section{Empirical Studies on International Risk Sharing}

There is a rich empirical literature studying various dimensions of international risk sharing. We divide this literature into three categories. The first category includes studies focusing on the patterns of international correlations of output and consumption to determine the degree of risk sharing. The second comprises studies that test the hypothesis of perfect 
risk sharing using regression models. The third category includes studies that employ various regression models to measure the extent of risk sharing and to examine the impact of financial flows on the degree of risk sharing. Our paper is closely related to those in the last category, although our empirical work encompasses the first two approaches as well.

\section{III.1. Studies on the Patterns of Output and Consumption Correlations}

Numerous studies have documented a variety of stylized facts associated with the patterns of cross-country comovement of output and consumption in order to examine the extent of risk sharing. These studies differ in terms of country coverage (developed versus developing), the correlations that they focus on (cross-country consumption correlations versus correlations of consumption with a global aggregate), and empirical techniques (simple correlations versus more sophisticated measures of comovement).

Obstfeld $(1994,1995)$ documents the cross correlations of consumption and output growth rates between individual countries and the rest of the world using PWT data for a group of developed and developing countries over the period 1950-1988. He finds that correlations of consumption growth rates are lower than those for output for the majority of the countries. His results also indicate that there was an increase in these correlations after 1973 for most of the industrial countries in his sample, which he interprets as an indication of increased international trade in financial assets after 1973.

Using two datasets-- PWT (1950-90) and OECD (1955-73)--Pakko (1998) finds that cross-country output correlations are higher than consumption correlations, but notes that his results are somewhat sensitive to the choice of dataset and detrending method. His results also suggest that correlations between consumption and domestic output are generally higher than those between consumption and world output, contrary to the predictions of theory. Using quarterly data for OECD countries over the period 1960-2000, Ambler, Cardia, and Zimmermann (2004) conclude that cross-country consumption correlations are quite low even in the period 1973-2000. Using a similar dataset, Canova and Ravn (1997) find that consumption correlations are significantly different from unity in almost all country pairs. They also find that the correlations are sensitive to the method of detrending.

Kose, Prasad, and Terrones (2003) employ annual data over the period 1960-1999 for a sample of 76 countries - 21 industrial and 55 developing - to examine the correlations of 
output and consumption growth rates in each country with the growth rates of composite measures of world output and consumption. They document that, on average, industrial countries have stronger output and consumption correlations with world aggregates than do developing economies. They find that consumption correlations are typically smaller than output correlations. For industrial countries, these correlations on average increase sharply in the 1970 s and rise further in the 1990s. For developing countries, they decline in the $1990 \mathrm{~s}^{4}$

Kose, Otrok, and Whiteman (2003) provide further empirical evidence about the extent of imperfect consumption risk sharing. They estimate a dynamic factor model using data for 60 developed and developing countries over the period 1960-1990. They find that the world and region-specific factors together account for a larger share of fluctuations in output growth than in consumption growth. In most countries, country-specific factors play a more important role than those two common factors in explaining consumption fluctuations.

Taken as a whole, the results of this vast literature indicate that the theoretical predictions regarding perfect risk sharing do not have much empirical support. First, the observed cross-country correlations of consumption fluctuations are relatively low. Second, these correlations are lower than those of output. Third, correlations between consumption and domestic output are generally higher than those between consumption and world output.

\section{III.2. Studies on Tests of Perfect Risk Sharing}

In addition to the basic stylized facts surveyed above, researchers have employed more rigorous methods to test the risk sharing implications of models with financial integration. These tests generally use some versions of reduced form solutions (or the first order conditions) of the models and focus on the links between various measures of domestic consumption and world consumption. ${ }^{5}$

Obstfeld (1995) examines the empirical links between domestic consumption growth and world consumption growth for the G7 economies. Based on the reduced form solutions of a simple endowment economy, he develops a test of the hypothesis of perfect consumption

\footnotetext{
${ }^{4}$ Recent studies looking at the time profile of cross-country correlations of output and consumption do not reach a clear conclusion, even for industrial countries (see Kose, Prasad, and Terrones, 2003 and Kose, Otrok, Whiteman, 2005 for summaries of recent studies).

${ }^{5}$ Cochrane (1991) and Mace (1991) provide early examples of these types of tests using consumer level data and analyzing the extent of risk sharing between individual and aggregate consumption.
} 
risk sharing. In particular, he runs a regression of the growth rate of domestic consumption on world consumption growth and national output growth. The model implies that the coefficient on world consumption should be one and that on national output should be equal to zero under perfect risk sharing. His results suggest that that the hypothesis of perfect risk sharing is rejected in most cases during the periods 1951-1972 and 1973-1988.

Lewis $(1996,1997)$ examines the roles played by nonseparabilities between tradables and nontradable leisure (or goods) and the restrictions on financial flows in explaining the lack of international risk sharing. She finds that, while formal tests reject risk sharing even among countries with relatively loose capital controls, correlations between domestic consumption and output appear to be higher for countries with more restrictions. She concludes that neither nonseparabilities between consumption and leisure, nor the inclusion of nontradables and/or durable goods, is sufficient to explain imperfect risk sharing.

\section{III.3. Studies on the Channels and Extent of Risk Sharing}

The empirical tests of the risk sharing hypothesis that we have discussed cannot shed light on the channels through which risk sharing takes place or about the extent of risk sharing. Asdrubali, Sørenson and Yosha (1996) develop a methodology to measure the extent of risk sharing achieved through different channels. They quantify the amount of risk sharing across U.S. states by decomposing the cross-sectional variance of gross state product data into various components representing different channels of risk sharing. ${ }^{6}$ They find that roughly 40 percent of shocks to gross state product are insured by capital markets, 13 percent by the federal government, and 23 percent by credit markets. Sørenson and Yosha (1998) use the same methodology to analyze the patterns of international risk sharing among European Community and OECD countries. They document that approximately 40 percent of shocks to GDP are insured in both groups. ${ }^{7}$

\footnotetext{
${ }^{6}$ Their paper is related to a voluminous literature on intranational risk sharing (using data from regions within a country), which concludes that that risk sharing is imperfect on that dimension as well but exceeds the degree of international risk sharing (see Hess and van Wincoop, 2002).

${ }^{7}$ Kalemli-Ozcan, Sørenson and Yosha (2006) study the evolution of risk sharing in the European Union using the same methodology. Kalemli-Ozcan, Sørenson and Yosha (2001a, 2001b) consider the empirical links between risk sharing and industrial specialization.
} 
Using the same methodology, recent studies attempt to quantify the extent of international consumption risk sharing and examine how financial integration facilitates risk sharing. Sørenson, Yosha, Wu and Zhu (2006) document that the extent of risk sharing among industrial countries rose during the late 1990s while home bias in debt and equity holdings declined. They detect a positive association between foreign portfolio assets and the extent of risk sharing; a similar result holds when they look at stocks of FDI. Giannone and Reichlin (2006) find an increase in the extent of risk sharing among European countries during the early 1990s, when financial integration in Europe had started gaining momentum.

Artis and Hoffmann (2006a,b) argue that, in order to capture the low-frequency comovement of output and consumption, the risk sharing regressions used by Sørenson et al. should be run on the levels of consumption and output rather than their growth rates. They do not find any increase in the extent of risk sharing over time among the OECD, EU, and EMU country groups when they estimate cross-section regressions based on the growth rates of consumption and output. However, when they estimate regressions using levels of the same variables, they find a noticeable increase in "long-run" consumption risk sharing among all three country groups, with greater risk sharing among countries with higher degrees of financial integration (measured by the amount of international financial assets they trade).

Some studies focus on the regression framework used by Obstfeld (1994) to evaluate changes over time in the extent of risk sharing. Bai and Zhang (2005) employ a dataset comprising 21 industrial and 19 developing countries. They find that there is no significant change in the regression coefficients from 1973-85 to 1986-98. Moser, Pointner and Scharler (2003) run the same regression for $15 \mathrm{EU}$ countries and formally test the stability of the regression coefficients over time. They do not find any break points in the regression coefficients over the period 1960-2002. They interpret these results as indicating the absence of any improvement in the extent of risk sharing.

Another branch of the literature analyzes how international correlations of output and consumption have been affected by financial globalization. For example, Kose, Prasad, and Terrones (2003) examine the factors that influence output and consumption correlations of individual country macroeconomic aggregates with the corresponding world aggregates. Their results indicate that actual gross capital flows - a measure of de facto financial integration - have no significant impact on output correlations. In the case of consumption 
correlations, they report even weaker findings. They conclude that there is little evidence that financial globalization has influenced consumption comovement across countries. ${ }^{8}$

\section{Dataset}

We examine patterns of international consumption risk sharing using a large dataset that includes industrial as well as developing countries. The basic data are taken from the Penn World Tables Version 6.2 (Heston, Summers, and Aten, 2006) and the World Bank's World Development Indicators. Per capita real GDP, real private consumption, and real public consumption constitute the measures of national output, private consumption and government consumption, respectively. All data are in constant (2000) international prices. Our measures of financial integration are from the External Wealth of Nations Database (Lane and Milesi-Ferretti, 2006). Data on institutional quality are based on the International Country Risk Guide, and data on domestic credit to the private sector are from Beck et. al. (2000). Our dataset comprises annual data over the period 1960-2004 for 69 countries (see the list of countries in the Appendix).

Our sample consists of two groups of countries - industrial (21) and developing (48). The group of industrial countries corresponds to a sub-sample of the OECD economies for which data used in the empirical analysis are available. We further divide developing countries into two coarse groups-21 emerging market economies (EMEs) and 27 other developing countries. As we discuss in the next section, the EMEs account for a substantial fraction of net capital flows from industrial to developing countries in recent decades. ${ }^{9}$

It is essential to isolate the impact of common shocks from that of financial globalization in order to evaluate the effects of globalization on international consumption risk sharing. We consider the period from 1960 to 2004 as being composed of three distinct sub-periods. The first, 1960-1972, corresponds to the Bretton Woods (BW) fixed exchange rate regime for the major industrial countries. This sub-period is characterized by the steady nature of growth and relatively mild business cycles around the world. The second

\footnotetext{
${ }^{8}$ Imbs (2006) uses a simultaneous equation approach to examine the impact of trade and financial flows on cross-country output and consumption correlations. His results suggest that the impact of financial flows on output correlations is larger than that on consumption correlations.

${ }^{9}$ This classification results in a set of EMEs that roughly corresponds to the group included in the MSCI emerging markets stock index.
} 
period, 1973-1986, witnessed a set of common shocks associated with sharp fluctuations in the price of oil and contractionary monetary policy in major industrial economies. Of course, the first and second periods are also different because of the difference in exchange rate regime. ${ }^{10}$ The third period, 1987-2004, represents the modern era of globalization in which there have been dramatic increases in the volumes of cross-border trade and financial flows.

From the perspective of understanding the effects of globalization on risk sharing, the third period is of the most interest. As documented by Kose, Prasad, Rogoff, and Wei (2006), private capital flows from industrialized economies to developing economies have increased dramatically since the mid-1980s, with the bulk of this increase going to the emerging market economies. This increase in trade and financial flows has been fueled by a series of trade and financial liberalization programs undertaken since the mid-1980s. Roughly 30 percent of the countries in our sample had liberalized their trade regimes in 1986; by 2004, this share had risen to almost 85 percent. The share of countries with open financial accounts rose from 20 percent to about 55 percent over this period.

\section{Basic Stylized Facts: Correlations of Output and Consumption}

We begin by providing a broad overview of the basic stylized facts about domestic and international correlations of the growth rates of output and consumption. We then study the temporal evolution of these correlations for evidence of whether the degree of risk sharing has changed as a result of rising financial linkages.

The four theoretical predictions documented in section II guide us to the relevant correlations to examine. In a complete markets framework with perfect risk sharing: (i) domestic consumption is only weakly correlated (or uncorrelated) with national output; (ii) cross-country correlations of consumption are equal to unity (or are very high); (iii) crosscountry correlations of consumption are much higher than those of output; and (iv) domestic consumption is more highly correlated with world consumption than with national output.

As countries become more integrated into global financial markets and effectively use them for risk sharing purposes, one would expect any differences between theoretical predictions and data to become smaller. To get at this issue, in addition to the correlations for

\footnotetext{
${ }^{10}$ However, it is debatable whether (and how) the monetary regime affects the properties of business cycle fluctuations in key macroeconomic aggregates (see Kose, Otrok and Whiteman, 2005).
} 
the full sample (1960-2004), we examine the correlations in specific sub-periods and changes over time in different sets of correlations. We present results separately for industrial countries and all developing countries. Within the group of developing countries, we report results separately only for emerging markets in order to keep the volume of results manageable and since that is the group of most interest to us for purposes of examining the effects of financial integration on risk sharing.

\section{Correlations between Domestic Consumption and Output}

The first column of Table 1 shows the cross-sectional medians of the correlations of private, public, and total consumption growth with the growth rate of output for the full sample period. That is, we compute the relevant correlation for each country and then, for each group of countries, report the cross-sectional medians of those country-specific correlations. The medians of private consumption correlations with output appear to be quite high, between 0.6 and 0.8 , for all country groups. The median correlation between private consumption and output is higher than that between public consumption and output in all country groups. Among developing countries, total consumption is more correlated with output than is private consumption. This is primarily driven by the high correlation between public consumption and output in these countries - probably a manifestation of procyclical fiscal policies (Kaminsky, Reinhart and Vegh, 2004).

The remaining columns of Table 1 show the changes in these correlations over time. We break up the full sample period into three periods as discussed earlier. ${ }^{11}$ It is difficult to discern any clear patterns in the evolution of these correlations. One interesting result is that, for emerging markets, there is a fall in correlations of private consumption with output during the common shocks period and then an upward spike in these correlations during the globalization period. The correlations based on total consumption also increase significantly in the globalization period for emerging market economies. A literal interpretation of this result is that the degree of risk sharing has declined for emerging market economies during the globalization period.

\footnotetext{
${ }^{11}$ We experimented with sub-periods with shorter lengths and computed cross-sectional means rather than medians of correlations. Neither of these had much impact on the findings reported here.
} 
Figure 1 shows the median correlations of the growth rate of output with that of private consumption, public consumption and total consumption computed over a 9-year rolling window for each country group. These figures are consistent with the broad patterns described in Table 1, indicating that the breakdown of the data into specific time periods is not driving the results. In the case of the correlations between private consumption and output, there appears to be a modest upward trend for emerging markets since the early 1980s while they are generally stable over time among the industrial countries. This trend is the opposite of what would be expected with better risk sharing.

These results are suggestive of the low levels of international risk sharing, even during the period of globalization. Emerging market economies appear not to have been able to decouple the fluctuations in their private consumption from those in domestic output even though they have registered a significant increase in trade of international financial assets. Even among industrial economies, there appears to be limited change in the degree of comovement between domestic consumption and national output.

\section{International Correlations}

We now turn our attention to the correlations of output and consumption growth rates in each country with the growth rates of the composite measures of the respective world aggregates. ${ }^{12}$ Table 2 shows that, on average, industrial countries have stronger correlations with world aggregates than developing economies over the full sample. For industrial countries, output correlations increase sharply in the common shock period and rise further in the period of globalization. In the case of emerging markets and developing countries, these correlations have registered a slight decline in the globalization period.

Contrary to the predictions of theory about perfect risk sharing environments, for all groups of countries the correlations of private consumption with world consumption are far

\footnotetext{
${ }^{12}$ The world aggregates are proxied by industrial country aggregates (all in per capita terms). These aggregates are the same for all developing countries, including emerging market economies, but vary across industrial countries (for them, the world aggregate is calculated using data only from the other industrial countries). The use of industrial country aggregates as proxies for world aggregates is preferable since most international financial flows are with these countries and, thus, risk sharing is more likely to be observed with this country group. This aggregate gives us the best shot at finding high and increasing levels of risk sharing, which of course is not what we find. In any case, we did experiment with other aggregates (G-7, world etc.) and find broadly similar results.
} 
less than unity and in most cases are quite low. Moreover, in an even more striking contrast with conventional theoretical predictions, for all country groups these correlations are lower than those of output with world output.

Have these correlations changed over time? Correlations of private consumption with world consumption on average increase modestly in the globalization period for industrial countries, but they do not change much for the other groups. Most of the consumption correlations for developing countries hover around zero. Correlations of public consumption exhibit similar patterns.

Figure 2 presents the median correlations of growth rates of output, private, public, and total consumption for the three groups of countries with the growth rates of the corresponding world aggregates computed over a 9-year rolling window. These figures are generally in line with the patterns described in Table 2. For industrial countries, there has been an increase in both output and private consumption correlations over time. The figures for emerging market countries show that these correlations have been declining over most of the period 1970-1990.

Figure 3 provides a different view of the evolution of correlations and presents all of the correlations for a particular group of countries in one panel. In particular, these figures are helpful in understanding how the extent of the "quantity anomaly" - the deviation of facts from theory, which predicts cross-country consumption correlations that are higher than those of output - has changed over time. Although this anomaly is quite apparent in both industrial countries and emerging markets, it has become more severe for the emerging market economies after the early 1990s as the gap between output and consumption correlations has begun to widen for this group.

Another implication of theory is that the correlation between domestic consumption and domestic output is lower than that between domestic consumption and world output. Is this the case in the data? Figure 4 shows the median correlations between growth rates of domestic consumption and output and between the growth rates of domestic consumption and world output computed over 9-year rolling windows for the period 1960-2004. These figures suggest that, contrary to the predictions of theory, the correlation between domestic consumption and output is typically higher than that between domestic consumption and 
world output. The gap between the two correlation measures is much wider in the case of emerging markets and other developing countries than for industrial economies.

In line with results reported in earlier studies, these correlations paint a grim picture about the extent of consumption risk sharing observed in the data. While industrial countries appear to have higher correlations of consumption and output with the corresponding world aggregates, these correlations are lower for developing countries and, if anything, have declined slightly during the period of globalization. This is a particularly interesting result for emerging market economies. It seems at odds with the notion that financial integration should have helped these economies, which have received the bulk of international capital flows to developing countries, to better share risk with the rest of the world.

The unconditional correlations presented in this section have helped obtain a preliminary assessment of the relevance of certain theoretical predictions about risk sharing, but they have obvious limitations. We now turn to a more formal analysis of the roles played by factors, such as common shocks and the increase in trade and financial linkages, in explaining the extent of comovement of macroeconomic aggregates.

\section{Evolution of Consumption Risk Sharing}

We analyze how the extent of international consumption risk sharing has evolved over time using three different approaches. Our first approach closely follows that of Sorenson, Yosha, Wu and Zhu (2006) and involves year-by-year estimation of a crosssection regression of the country-specific component of consumption growth (measured as a deviation of domestic consumption growth from the world consumption growth) on the country-specific component of output growth. The second approach is similar to the first one but, relying on the idea advanced by Obstfeld (1995), involves running the same regression equation for each country over a given time interval. The third approach is a combination of the first two as it involves estimation of the same underlying model in a panel framework. ${ }^{13}$

\footnotetext{
${ }^{13}$ We also experimented with regressions using levels rather than the growth rates of consumption and output (Artis and Hoffman, 2006a). With this approach, the evolution of the coefficient estimates is rather smooth, but the general message about the extent of risk sharing and its evolution was no different from that of the other three approaches.
} 


\section{Cross-Section Regressions (Year-by-Year)}

We estimate the following regression equation for each year for the full sample as well as for each country group:

$$
\Delta \log c_{i t}-\Delta \log C_{t}=\alpha_{t}+\beta_{c t}\left(\Delta \log y_{i t}-\Delta \log Y_{t}\right)+\varepsilon_{i t}
$$

where $c_{i t}\left(y_{i t}\right)$ denotes per capita consumption (GDP) of country $i$ in year $t, C_{t}\left(Y_{t}\right)$ is world per capita consumption (GDP). This is the standard risk sharing equation employed in several earlier studies. ${ }^{14} C_{t}$ and $Y_{t}$ are, respectively, measures of aggregate (common) movements in consumption and output. Since it is not possible to share the risk associated with common fluctuations, the common component of each variable is subtracted from the corresponding national variable. The difference between the national and common world component of each variable captures the idiosyncratic (country-specific) fluctuations in that variable.

In a model with complete international financial markets and perfect risk sharing, the left hand side of the equation should be zero implying that the coefficient $\beta_{c t}$ is equal to zero. Asdrubali, Sørenson and Yosha (1996) show how this coefficient could be useful in measuring the extent of risk sharing, which depends on the extent to which idiosyncratic consumption fluctuations are buffered against idiosyncratic GDP fluctuations. The average degree of synchronization between the countries' consumption and their GDP growth in year $t$ is measured by the coefficient $\beta_{c t}$. The smaller the extent of idiosyncratic comovement, $\beta_{c t}$, the higher the extent of international risk sharing. We estimate this regression for each year over 1960-2004 and trace the evolution of estimates of $\left(1-\beta_{c t}\right)$ in order to evaluate the changes in the extent of risk sharing over time. This variable should typically range from 0 (no risk sharing) to 1 (perfect risk sharing).

Since the estimates of $\left(1-\beta_{c t}\right)$ fluctuate from year to year, we smooth them by computing their average over a 9-year rolling window. Figure 5 shows that, for the full sample, the extent of risk sharing appears to increase in the globalization period, but it is lower than the levels observed during the late 1970s. The degree of risk sharing is higher among industrial countries than other country groups. Moreover, it rises modestly for the

\footnotetext{
${ }^{14}$ For extended discussions of the derivation of this equation, see Obstfeld and Rogoff (2004, Chapter 5), Asdrubali, Sørenson and Yosha (1996), and Sørenson and Yosha (1998).
} 
group of industrial countries during the late 1990s, but to a level that is not much above that seen in the 1970s. There is little evidence that the period of globalization has seen a marked increase in risk sharing capabilities of emerging markets and other developing countries.

\section{Time Series Regressions (For Each Country)}

Next, we run the same regression but, rather than estimating it for each year, we estimate it for each country over rolling nine-year periods starting from 1960. In other words, the regression equation takes the form:

$$
\Delta \log c_{i t}-\Delta \log C_{t}=\alpha+\beta_{c i t}\left(\Delta \log y_{i t}-\Delta \log Y_{t}\right)+\varepsilon_{i t}
$$

where $\beta_{c i t}$ is country-specific and varies over time. This is similar to the regressions used by Obstfeld (1995), who estimates his models for each country for different periods and analyzes the changes in the relevant coefficients over time. After running the regression for each country, we compute the median of $\beta_{c i t}$ over the country sample for each period.

Figure 6 presents the plots of the extent of consumption risk sharing, measured by the median of $\left(1-\beta_{c i t}\right)$ for the full sample and for each country group. In other words, the extent of risk sharing in 1969 in each panel refers to the median of (1- $\left.\beta_{c i t}\right)$ of the respective country group and $\beta_{c i t}$ is the regression for country $i$ over the period 1961-1969. For industrial countries, there is a steady and substantial increase in the degree of risk sharing, with the increase most noticeable during the globalization period. By contrast, both emerging market economies and the group of developing countries experience a decline in the degree of risk sharing during the period of globalization.

\section{Panel Regressions}

Our next approach combines the first two by estimating the standard regression model in a panel framework. In particular, we run the same regression but estimate it over nine-year rolling panels. This allows us to utilize all the time series and cross-sectional information available in the data. Figure 7 presents plots of the extent of consumption risk sharing based on the panel regressions. The extent of risk sharing in 1969 is again equal to $\left(1-\beta_{c t}\right)$ and $\beta_{c t}$ is the coefficient from the panel regression covering the period 1961-1969. The patterns in 
these figures are broadly consistent with our earlier results. While industrial countries attain slightly better risk sharing outcomes during the period of globalization, neither emerging markets nor developing countries exhibit the same pattern.

The general message of this section is that industrial countries have attained improvements in risk sharing during the period of globalization, although this is still not much of an improvement over the degree of risk sharing in the 1970s. Emerging market economies and other developing economies have not registered any major changes during the period of globalization in terms of their ability to share idiosyncratic income risk. These temporal patterns are suggestive, but do not directly address the question of whether financial globalization has played an important role in the evolution of the degree of risk sharing displayed by different country groups. So we now turn to a regression model that augments the standard risk sharing regression with an interaction variable in order to explicitly capture the effects of financial globalization.

\section{Financial Globalization and Risk Sharing}

We use panel regression techniques to directly examine the impact of financial globalization on the degree of risk sharing. We first discuss how to measure the extent of a country's integration into international financial markets. We then present results from a set of benchmark panel regressions using annual data. Next, we turn our attention to the relationship between financial globalization and risk sharing over different time horizons using data differenced at three and five year frequencies. In addition, we account for some potential endogeneity issues by employing dynamic panel regression models.

\section{Measuring Financial Globalization}

What is the relevant measure of financial integration for analyzing the dynamics of risk sharing? The measure typically used in the literature is a de jure indicator of capital account openness, based on compilations of the restrictions a country imposes on crossborder capital account transactions. However, as argued by Kose, Prasad, Rogoff and Wei (2006), de jure measures - no matter how sophisticated - cannot capture the enforcement and effectiveness of capital controls, and may therefore not be indicative of the true extent of financial integration. More importantly, a country's ability to share its consumption risk 
hinges on its actual trade of financial assets with other countries, not simply its policy regime regarding international financial transactions. Hence, de facto measures of integration may be more relevant for examining the role of financial integration in driving risk sharing patterns. Moreover, gross positions of foreign assets and liabilities provide a good indication of how much risk can be shared by a country through international financial markets, even if observed period-by-period net flows are small. We use measures of gross stocks of foreign assets and liabilities (all scaled by GDP) as alternative measures of financial openness. ${ }^{15}$

\section{Benchmark Results: Panel Regressions}

To analyze the impact of financial integration on the extent of risk sharing, we interact the idiosyncratic component of output with various measures of financial integration. That is, we estimate the following regression using panel data:

$$
\Delta \log c_{i t}-\Delta \log C_{t}=\alpha+\mu\left(\Delta \log y_{i t}-\Delta \log Y_{t}\right)+\gamma F O_{i}\left(\Delta \log y_{i t}-\Delta \log Y_{t}\right)+\varepsilon_{i t}
$$

where $F O_{i}$ measures the degree of financial openness of country $i$. Parallel to the analysis in the previous section, the degree of risk sharing attained by country $i$ is equal to $\left(1-\mu-\gamma F O_{i}\right) .{ }^{16}$ When the interaction term, $\gamma$, is negative, it indicates that the greater the degree of financial integration, the higher the amount of risk sharing achieved by a country. The panel regressions we employ include both country fixed effects and time effects.

In Table 3, we report the results for different country groups and also separately for the full sample (1960-2004) and the period of globalization (1987-2004). We focus on three measures of financial openness and experiment with each in turn: gross stocks (the sum of stocks of foreign assets and liabilities), stocks of assets, and stocks of liabilities.

The first and fifth columns of the table show the results of panel regressions without interaction terms associated with financial integration. The findings are broadly consistent

\footnotetext{
${ }^{15}$ We also experimented with several de jure measures of restrictions on capital account transactions. The results indicate that these measures do not have a significant effect on the degree of risk sharing. ${ }^{16}$ See Sørenson et al. (2006) for a similar model. We also estimated models controlling for potential time trends associated with the measures of financial integration, but none of these trends was statistically significant.
} 
with the results reported in the previous section. In particular, the extent of risk sharing appears to be slightly higher in industrial countries than in developing countries; it is lowest for the group of emerging market economies.

For the full sample period, none of the interaction coefficients is significant for all countries and the group of industrial economies, and they are in fact positive-implying a deterioration in risk sharing - for emerging markets. In other words, it is difficult to claim that financial globalization has had a beneficial effect on the amount of risk sharing around the world over the period 1960-2004. The results look more promising when we restrict our analysis to the period of globalization. Higher levels of gross stocks of foreign assets and liabilities, as well as just higher levels of liabilities, improve risk sharing, as indicated by the negative interaction coefficients in columns 6 and 8. However, this result seems to be driven almost entirely by industrial countries, since it is only for that group that the coefficients on the financial integration interaction variables are all significantly negative. In the case of emerging markets, financial integration appears to have no significant impact in the globalization period. These results echo our findings in the previous section that the risk sharing benefits of financial integration have accrued only to industrial countries.

Based on the specifications we have estimated, it is possible to trace out the marginal effect on risk sharing of a change in the level of financial integration. Figure 8 shows the relationship between the degree of risk sharing and various measures of financial openness, along with a 95 percent confidence interval. The plots also show the distribution of the financial openness measures for the countries in the relevant samples. Since the coefficients on the interaction terms are negative for industrial countries (see Table 3), the slopes of the measures of risk sharing $\left(1-\mu-\gamma^{*} \mathrm{FO}\right)$ are of course positive. For instance, the point estimates indicate that a 10 percentage points of GDP increase in the stock measure of financial openness (which has a mean of 266 percent of GDP) would be associated with an increase of 0.002 in the level of risk sharing. By contrast, a similar increase in the asset (liability) stock measure of financial openness (which has a mean of 127 (138) percent of GDP) would be associated with an increase of 0.004 in the level of risk sharing. 


\section{Why is There So Little Risk Sharing?}

The results that we have presented thus far suggest that the degree of international risk sharing is limited. Furthermore, only industrial countries seem to have attained clear benefits from financial integration in terms of improved risk sharing. Why is it that even emerging markets, which have attained much higher levels of financial integration than other developing economies, have been able to see few benefits in this dimension? In this section, we investigate two possibilities. One is that different types of capital flows may be more or less conducive to risk sharing, and emerging markets may just not be getting the "right" types of flows. Another possibility is that, despite increased financial integration, there are other features of these countries - either structural features or policies - that preclude them from attaining improved risk sharing through financial integration.

\section{VIII.1 Does the Composition of Flows and Stocks Matter?}

Are specific types of financial assets more conducive to attaining the risk sharing benefits of globalization? To address this question, we now consider disaggregated measures of financial integration. In particular, we focus on the stock measures of foreign direct investment (FDI), Equity (portfolio equity), Debt (portfolio debt) and FDI plus Equity. We also examine the effects of FDI+Equity and Debt when we include them simultaneously.

Table 4 presents the results of benchmark panel regression with these finer measures of financial integration for the full sample and globalization periods. For the full sample, results based on various combinations of FDI and equity indicate that these categories do promote risk sharing during the globalization period. The interaction coefficients associated with these measures are negative and significant for all countries and the full group of developing countries. Debt stocks seem to have no role in promoting risk sharing in industrial countries. Interestingly, for emerging market economies, neither stocks of FDI nor equity seem to help in sharing risk while debt stocks clearly reduce the level of risk sharing. ${ }^{17}$

Putting this result together with the fact that, until recently, portfolio debt dominated the external liability positions of emerging markets could explain why these economies have

\footnotetext{
${ }^{17}$ There appears to be a systematic empirical link between exposure to short-term debt and the likelihood of financial crises (see Rodrik and Velasco, 2000). A similar result is reported in the literature on early warning systems (Berg, Borenzstein, and Pattillo, 2004, survey this literature).
} 
not attained the risk-sharing benefits of financial globalization. However, it still leaves open the question of why the rising importance of FDI and portfolio equity stocks has not yet resulted in a marked improvement in risk sharing achieved by these economies. ${ }^{18}$

\section{VIII.2 Do Certain Country Characteristics Affect Risk Sharing?}

It is possible that the inability of emerging markets to attain improved risk sharing through financial integration is related to weaknesses in the domestic policy environment or structural factors. We examine the role of three factors - trade openness (the sum of exports and imports to GDP), the level of financial sector development (crudely measured as the ratio of domestic credit to GDP), and a measure of institutional quality. ${ }^{19}$ Table 5 indicates that, over the full sample, higher trade openness is associated with better risk sharing among developing countries, while better institutional quality is associated with less risk sharing. This latter result is puzzling but, reassuringly, it is reversed in the globalization period. Again, none of these country characteristics seems to matter for the degree of risk sharing attained by emerging market economies.

Finally, we combined these two possible explanations for weak risk sharing by running the regressions separately for each flow and stock measure of integration discussed in the previous sub-section, and including in those regressions interactions of those measures with the three country characteristics noted in the last paragraph (multiplied by the basic coefficient of interest - the one on output growth--to capture the marginal effect of the integration-financial development interaction). We just briefly summarize the main results here. Among industrial countries, we find that the interaction of financial integration with

\footnotetext{
${ }^{18}$ Kose, Prasad, Rogoff and Wei (2006) discuss changes in the composition of external assets and liabilities over time. They report that the share of debt in gross stocks of foreign assets and liabilities has declined from 75 percent in 1980-84 to 59 percent in 2000-2004 in a group of 71 developed and developing countries. For emerging markets, the share of FDI and portfolio equity has risen from a total of 13 percent in 1980-84 to 37 percent in 2000-2004, while the share of debt has declined from 78 percent to 47 percent over the same period.

${ }^{19}$ In these regressions, we use binary variables to represent the variation in country characteristics. Each variable is equal to 1 for countries that are above the group median level of the respective country characteristic and 0 otherwise in each year. The index of institutional quality is constructed as the sum of three ICRG indexes (corruption, law and order, and bureaucratic quality) and takes on values between 0 and 18. A higher value reflects better institutions.
} 
measures of domestic financial development does indeed improve risk sharing, but this effect is absent for developing countries and emerging market economies.

Interestingly, the one positive result we find is that trade integration combined with financial integration does in fact improve risk sharing for emerging market economies. In other words, financial integration seems to work in terms of delivering risk sharing benefits only when the economy is also open to trade flows.

\section{Conclusion}

In this paper, we examined the implications of increased financial integration for the patterns of international risk sharing among different groups of countries using three empirical approaches. First, we documented some summary statistics on the correlations of growth rates of output and consumption of each country with their corresponding world aggregates. For industrial countries, these correlations increase during the period of globalization. In contrast, for emerging market economies, these correlations do not change much in this period. Second, we study the evolution of the extent of risk sharing as measured by changes in the comovement between idiosyncratic components of the growth rates of consumption and output. The results suggest that industrial countries share more of their idiosyncratic consumption risk than emerging markets. Moreover, industrial countries have been able to increase the extent of risk sharing in the globalization period while emerging market economies experience a slight decline in the degree of risk sharing. Third, we analyzed the impact of international financial integration on the extent of risk sharing. We find it helps improve risk sharing outcomes in industrial countries but has no significant impact on the extent of risk sharing in emerging markets.

These congruent results from three empirical approaches point to an interesting puzzle. Theory predicts that financial integration should allow countries to improve the scope of international risk sharing by diversifying their idiosyncratic income risk. Contrary to theoretical predictions, however, emerging market economies--which as a group have experienced a significant increase in international financial flows during the past two decades--have been unable to enjoy the risk sharing benefits of financial globalization. We briefly examined whether the composition of capital stocks could explain this puzzle, and found that, in general, FDI and portfolio equity stocks seem to improve risk sharing 
outcomes while debt stocks have the opposite effect. Only the latter result comes through strongly for emerging markets, however. Country characteristics such as trade openness, financial development and institutional quality do not seem to play a big role in influencing the risk sharing outcomes for emerging markets.

Could measurement error in the consumption data for emerging markets be driving our puzzling results for this group of countries? It is highly unlikely that the temporal evolution of risk sharing patterns can be explained by measurement error. Indeed, if consumption is becoming better measured over time, it should be getting mechanically delinked from output, which would drive up estimates of risk sharing. Another approach to dealing with measurement error is to look at income smoothing, on the logic that income (measured as GNP or GNI) is better measured than consumption and reflects risk sharing via international financial flows. Sørenson et al. (2006) find that international financial flows help industrial countries to smooth their income since the early 1990s. Ultimately, it is smoothing of consumption rather than income that matters for welfare. Nevertheless, we did look at income smoothing in our empirical framework but found that emerging markets do little better in terms of using financial integration to improve income smoothing compared to consumption smoothing.

Our results suggest two avenues that should be explored in future work. The puzzle we have identified in this paper might be related to a threshold effect associated with the degree of financial integration since industrial countries that are substantially integrated into global financial markets do seem to enjoy the risk sharing benefits of financial globalization. This suggests that, in order to reap these benefits, emerging markets and other developing countries need to become more integrated into global financial markets.

Another reason for the inability of emerging market economies to attain the presumed risk sharing benefits of financial integration is that capital flows to emerging market economies tend to be procyclical-they increase in good times and fall in bad times. The very feature of procyclicality might be preventing emerging markets from utilizing these flows to smooth their consumption fluctuations. Since flows to these economies are shifting away from debt--which tends to be more procyclical--to FDI and portfolio equity flows-which tend to be more stable--it is possible that the risk sharing benefits of international financial integration will become more apparent for emerging markets in the future. 


\section{Appendix: List of Countries}

The sample comprises 69 countries--21 industrial and 48 developing. ${ }^{20}$

\section{Industrial countries}

Australia (AUS), Austria (AUT), Belgium (BEL), Canada (CAN), Denmark (DNK), Finland (FIN), France (FRA), Germany (DEU), Greece (GRC), Ireland (IRL), Italy (ITA), Japan (JPN), Netherlands (NLD), New Zealand (NZL), Norway (NOR), Portugal (PRT), Spain (ESP), Sweden (SWE), Switzerland (CHE), United Kingdom (GBR), and United States (USA).

\section{Developing countries ${ }^{21}$}

These countries are grouped into Emerging Markets (21) and Other Developing Countries (27).

\section{Emerging Market Economies}

Argentina (ARG), Brazil (BRA), Chile (CHL), China (CHN), Colombia (COL), Egypt (EGY), India (IND), Indonesia (IDN), Israel (ISR), Jordan (JOR), Korea (KOR), Malaysia (MYS), Mexico (MEX), Morocco (MAR), Pakistan (PAK), Peru (PER), Philippines (PHL), South Africa (ZAF), Thailand (THA), Turkey (TUR), and Venezuela (VEN).

\section{Other Developing Countries}

Algeria (DZA), Bolivia (BOL), Cameron (CMR), Costa Rica (CRI), Cote d'Ivoire (CIV), Dominican Republic (DOM), Ecuador (ECU), El Salvador (SLV), Fiji (FJ), Gabon (GAB), Ghana (GHA), Guatemala (GTM), Haiti (HTI), Honduras (HND), Iran (IRN), Jamaica (JAM), Mauritius (MUS), Nicaragua (NIC), Papua New Guinea (PNG), Paraguay (PRY), Senegal (SEN), Sri Lanka (LKA), Togo (TGO), Trinidad and Tobago (TTO), Tunisia (TUN), Uruguay (URY), and Zimbabwe (ZWE).

\footnotetext{
${ }^{20} \mathrm{We}$ excluded from the analysis small countries (those with population below 1 million), transition economies, major oil producers, and other countries with incomplete or clearly unreliable data.

${ }^{21}$ Hong Kong, Panama, and Singapore were excluded from the analysis because these countries are financial hubs and are therefore outliers in terms of standard measures of de facto financial integration.
} 


\section{References}

Artis, Michael J., and Mathias Hoffmann, 2006a, "Declining Home Bias and the Increase in International Risk Sharing: Lessons from European Integration,” (unpublished; Manchester: University of Manchester).

_ 2006b, "The Home Bias and Capital Income Flows Between Countries and Regions,” CEPR Discussion Paper No. 5691 (London: Centre for Economic Policy Research).

Albuquerque, Rui, 2003, “The Composition of International Capital Flows: Risk Sharing Through Foreign Direct Investment," Journal of International Economics, Vol. 61, No. 2, pp. 353-83.

Ambler, Steven, Emanuela Cardia, and Christian Zimmermann, 2004, "International Business Cycles: What are the Facts?" Journal of Monetary Economics, Vol. 51 (2), pages 257-276.

Asdrubali, Pierfederico, Bent E. Sorensen, and Oved Yosha, 1996, "Channels of Interstate Risk Sharing: United States 1963-90," Quarterly Journal of Economics, Vol. 111, No. 4, pp.1081-1110.

Backus, David, Patrick Kehoe, and Finn Kydland, 1995, “International Business Cycles: Theory and Evidence," in Frontiers of Business Cycle Research, ed. by Thomas Cooley (Princeton: Princeton University Press), pp. 331-356.

Bai, Yan, and Jing Zhang, 2005, "Financial Integration and International Risk Sharing" Working Paper, University of Michigan.

Baxter, Marianne, 1995, "International Trade and Business Cycles," in Handbook of International Economics Vol. III, ed. by Gene Grossman and Kenneth Rogoff (Amsterdam: North-Holland).

Beck, Thorsten, Asli Demirguc-Kunt and Ross Levine, 2000, "A New Database on Financial Development and Structure,” World Bank Economic Review 14, 597-605.

Berg, Andrew, Eduardo Borensztein, and Catherine Pattillo, 2004, “Assessing Early Warning Systems: How Have They Worked in Practice?” IMF Working Paper 04/52.

Bekaert, Geert, Campbell R. Harvey, and Christian Lundblad, 2006, "Growth Volatility and Equity Market Liberalization," Journal of International Money and Finance, forthcoming. 
Brandt, Michael, John Cochrane and Pedro Santa-Clara, 2006, "International Risk Sharing is Better Than You Think, or Exchange Rates are Too Smooth," Journal of Monetary Economics 53, 671-698.

Canova, Fabio, and Morten Ravn, 1996, "International Consumption Risk Sharing," International Economic Review, Vol. 37, No. 3, pp. 573-601.

Cochrane, John H, 1991, “A Simple Test of Consumption Insurance,” Journal of Political Economy, Vol. 99 (5), pages 957-76,

Giannone, Domenico, and Lucrezia Reichlin, 2006, “Trends and Cycles in the Euro Area: How Much Heterogeneity and Should We Worry About It?” ECB Working Paper No. 595 (London: European Central Bank).

Heathcote, Jonathan, Perri, Fabrizio, 2002, "Financial Autarky and International Business Cycles," Journal of Monetary Economics, Vol. 49 (3), 601-628.

— 2003, "Why Has the U.S. Economy Become Less Correlated With the Rest of the World?" American Economic Review, Vol. 93 (2), pp. 63-69.

— , 2004, "The International Diversification Puzzle Is Not as Bad as You Think," Working Paper, Georgetown University.

Hess, Gregory, and Eric van Wincoop, 2000, Intranational Macroeconomics, Cambridge University Press.

Heston, Alan, Robert Summers, and Bettina Aten, 2006, Penn World Tables Version 6.2, Center for International Comparisons, Income and Prices at the University of Pennsylvania.

Imbs, Jean, 2004. "Trade, Finance, Specialization, and Synchronization," Review of Economics and Statistics, Vol. 86 (3), 723- 734.

— , 2006, “The Real Effects of Financial Integration," Journal of International Economics, Vol. 68, No. 2 (March), pp. 296-324.

Imbs, Jean and Paolo Mauro, 2007, "Pooling Risk Among Countries," IMF Working Paper, forthcoming.

Kalemli-Ozcan, Sebnem, Bent E. Sørensen, and Oved Yosha, 2001a, "Risk Sharing and Industrial Specialization: Regional and International Evidence," American Economic Review, Vol. 93 (3), pp. 903-18. 
2001b, "Economic Integration, Industrial Specialization and the Asymmetry of Macroeconomic Fluctuations,” Journal of International Economics, Vol. 55, pp. 10737.

Kose, M. Ayhan, Eswar S. Prasad, and Marco E. Terrones, 2003a, "How Does Globalization Affect the Synchronization of Business Cycles?" American Economic Review, Vol. 93 (2), pp. 57-63.

_ 2003b, "Financial Integration and Macroeconomic Volatility," IMF Staff Papers, Vol. 50, No. 1 (Washington: International Monetary Fund).

Kose, M. Ayhan, Christopher Otrok, and Charles Whiteman, 2003, "International Business Cycles: World, Region, and Country Specific Factors," American Economic Review, Vol. 93, pp. 1216-39.

Kose, M. Ayhan, Christopher Otrok, and Charles Whiteman, 2005, "Understanding the Evolution of World Business Cycles,” IMF Working Paper No. 05/211.

Kose, M. Ayhan, Eswar S. Prasad, Kenneth Rogoff and Shang-Jin Wei, 2006, "Financial Globalization: A Reappraisal," IMF Working Paper 06/189.

Lane, Philip, and Gian Maria Milesi-Ferretti, 2006, "The External Wealth of Nations Mark II: Revised and Extended Estimates of Foreign Assets and Liabilities, 1970-2004," IMF Working Paper 06/69 (Washington: International Monetary Fund).

Leblebicioglu, Asli, 2006, "Financial Integration, Credit Market Imperfections and Consumption Smoothing," Working Paper, North Carolina State University.

Levchenko, Andrei A., 2005, "Financial Liberalization and Consumption Volatility in Developing Countries," IMF Staff Papers, Vol. 52, No. 2 (Washington: International Monetary Fund).

Lewis, Karen K., 1996, "What Can Explain the Apparent Lack of International Consumption Risksharing?” Journal of Political Economy, Vol. 104, No. 2, pp. 267-297.

— 1999, "Trying to Explain Home Bias in Equities and Consumption," Journal of Economic Literature, Vol. 37, June, 571-608.

Mace, Barbara, 1991, "Full Insurance in the Presence of Aggregate Uncertainty," Journal of Political Economy, Vol. 99, pp. 928-56.

Mélitz, Jacques, and Frédéric Zumer, 1999, "Interregional and International Risk Sharing and Lessons for EMU," Carnegie-Rochester Conference Series on Public Policy 51, pp. $149-88$. 
Moser, Gabriel, Wolfgang Pointer, and Johann Scharler, 2004, "International Risk Sharing in Europe: Has Anything Changed?" in The Economic Potential of a Larger Europe, ed. by K. Liebscher, J Christl, P. Mooslechner, and D. Ritzberger-Grünwald (Northampton: Edward Elgar Publishing), pp. 260-75.

Obstfeld, Maurice, 1994, “Are Industrial-Country Consumption Risks Globally Diversified?" in Capital Mobility: The Impact of Consumption, Investment and Growth, ed. by L. Leiderman and A. Razin (New York; Cambridge University Press), pp. 13-47.

, 1995, "International Capital Mobility in the 1990s," in Understanding Interdependence, ed. by P.B. Kenen (Princeton: Princeton University Press), pp. 201-261

and Kenneth Rogoff, 2001, "The Six Major Puzzles in International Macroeconomics Solved," NBER Macroeconomics Annual 2000, Vol. 15, No. 1, pp. 339-90.

— 2004, Foundations of International Macroeconomics (Cambridge: MIT Press).

Pakko, Michael, 2003, "Substitution Elasticities and Investment Dynamics in Two-Country Business Cycle Models," Topics in Macroeconomics, Berkeley Electronic Press, vol. 3(1), pages $1125-1125$.

— 1998, "Characterizing Cross-Country Consumption Correlations," Review of Economics and Statistics, Vol. 80, No. 1, pp. 169-174.

Prasad, Eswar S., Kenneth Rogoff, Shang-Jin Wei, and M. Ayhan Kose, 2003, Effects of Financial Globalization on Developing Countries: Some Empirical Evidence, IMF Occasional Paper No. 220 (Washington: International Monetary Fund).

Rodrik, Dani and Andres Velasco, 2000, "Short-Term Capital Flows," Annual World Bank Conference on Development Economics 1999 (Washington: World Bank), pp. 59-90.

Sorensen, Bent E., and Oved Yosha, 1998, "International Risk Sharing and European Monetary Unification," Journal of International Economics, Vol. 45, pp. 211-38.

— - Yi-Tsung Wu, and Yu Zhu , 2006, "Home Bias and International Risk Sharing: Twin Puzzles Separated at Birth," (manuscript, University of Houston).

Stockman, Alan, and Linda Tesar, 1995, "Tastes and Technology in a Two-Country Model of the Business Cycle: Explaining International Comovements," American Economic Review, Vol. 85, No. 1, pp. 168-85. 
Table 1. Correlations of Growth Rates of Selected Variables with Output

(Median for each Group of Countries)

\begin{tabular}{ccccc}
\hline & Full Sample & & \multicolumn{2}{c}{ Sub-Periods } \\
\cline { 2 - 3 } \cline { 5 - 6 } & & BW & $\begin{array}{c}\text { Common } \\
\text { Shocks }\end{array}$ & Globalization \\
\hline
\end{tabular}

\section{Private Consumption}

$\begin{array}{lrrrr}\text { All Countries } & 0.70 & 0.72 & 0.71 & 0.75 \\ & {[0.03]^{* * *}} & {[0.04]^{* * *}} & {[0.05]^{* * *}} & {[0.05]^{* * *}} \\ \text { Industrial Countries } & 0.77 & 0.70 & 0.75 & 0.81 \\ & {[0.03]^{* * *}} & {[0.12]^{* * *}} & {[0.04]^{* * *}} & {[0.04]^{* * *}} \\ \text { Developing Countries } & 0.63 & 0.72 & 0.59 & 0.61 \\ & {[0.05]^{* * *}} & {[0.05]^{* * *}} & {[0.08]^{* * *}} & {[0.09]^{* * *}} \\ \text { Emerging Markets }^{1 /} & 0.64 & 0.75 & 0.62 & 0.81 \\ & {[0.06]^{* * *}} & {[0.14]^{* * *}} & {[0.14]^{* * *}} & {[0.10]^{* * *}}\end{array}$

\section{Government Consumption}

$\begin{array}{lrrrr}\text { All Countries } & 0.37 & 0.32 & 0.36 & 0.36 \\ & {[0.04]^{* * *}} & {[0.05]^{* * *}} & {[0.05]^{* * *}} & {[0.04]^{* * *}} \\ \text { Industrial Countries } & 0.24 & 0.07 & 0.08 & 0.15 \\ & {[0.06]^{* * *}} & {[0.17]} & {[0.06]} & {[0.13]} \\ \text { Developing Countries } & 0.47 & 0.35 & 0.50 & 0.43 \\ & {[0.04]^{* * *}} & {[0.04]^{* * *}} & {[0.04]^{* * *}} & {[0.05]^{* * *}} \\ \text { Emerging Markets }^{1 /} & 0.50 & 0.33 & 0.50 & 0.54 \\ & {[0.08]^{* * *}} & {[0.08]^{* * *}} & {[0.09]^{* * *}} & {[0.09]^{* * *}}\end{array}$

\section{Total consumption}

$\begin{array}{lrrrr}\text { All Countries } & 0.72 & 0.71 & 0.72 & 0.73 \\ \text { Industrial Countries } & {[0.02]^{* * *}} & {[0.05]^{* * *}} & {[0.03]^{* * *}} & {[0.03]^{* * *}} \\ & 0.74 & 0.70 & 0.70 & 0.73 \\ \text { Developing Countries } & {[0.02]^{* * *}} & {[0.10]^{* * *}} & {[0.04]^{* * *}} & {[0.03]^{* * *}} \\ & 0.70 & 0.71 & 0.72 & 0.73 \\ \text { Emerging Markets }^{1 /} & {[0.03]^{* * *}} & {[0.06]^{* * *}} & {[0.06]^{* * *}} & {[0.06]^{* * *}} \\ & 0.72 & 0.71 & 0.72 & 0.86 \\ & {[0.06]^{* * *}} & {[0.10]^{* * *}} & {[0.13]^{* * *}} & {[0.06]^{* * *}}\end{array}$

Note: Standard errors are in brackets. The symbols *,**, and *** indicate statistical significance at the $10 \%, 5 \%$, and 1\% level, respectively. BW, Common Shocks and Globalization, refer to the periods 19611972, 1973-1986, and 1987-2004, respectively.

${ }^{1 /}$ Emerging Market Economies are part of the group of Developing Countries. 
Table 2. Correlations with World Aggregates ${ }^{1 /}$

(Median for each Group of Countries)

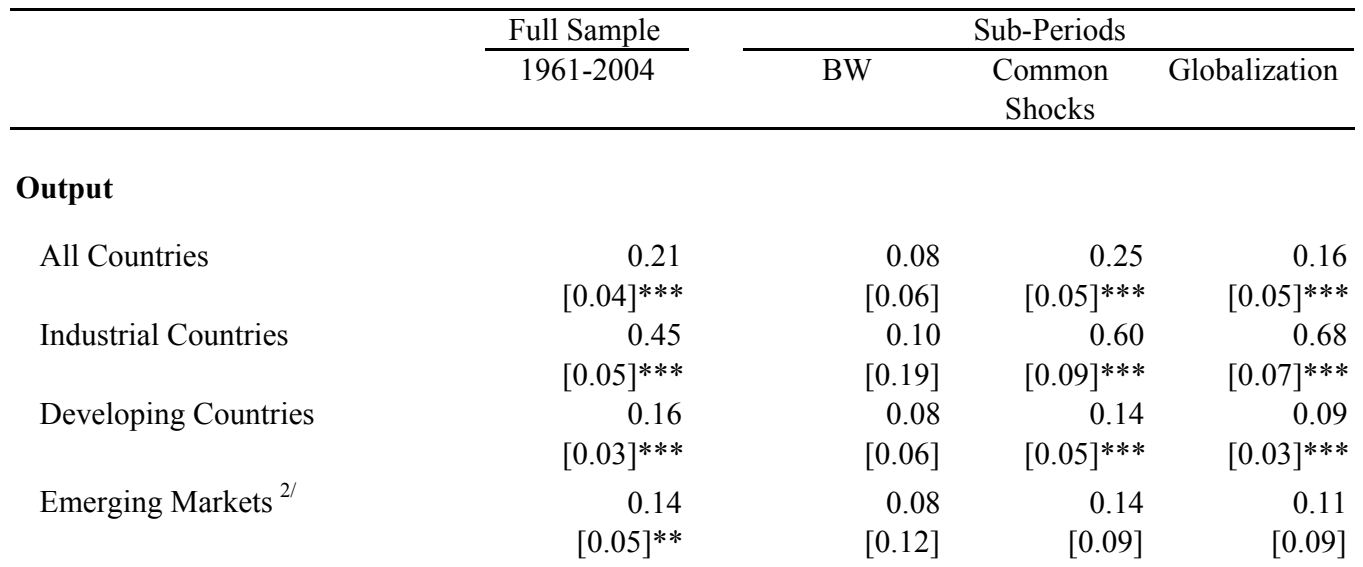

\section{Private Consumption}

$\begin{array}{lrrrr}\text { All Countries } & 0.17 & 0.12 & 0.10 & 0.07 \\ \text { Industrial Countries } & {[0.03]^{* * *}} & {[0.03]^{* * *}} & {[0.05]^{* *}} & {[0.05]} \\ & 0.29 & 0.07 & 0.24 & 0.33 \\ \text { Developing Countries } & {[0.03]^{* * *}} & {[0.07]} & {[0.10]^{* *}} & {[0.10]^{* * *}} \\ & 0.12 & 0.14 & 0.05 & -0.01 \\ \text { Emerging Markets }^{2 /} & {[0.01]^{* * *}} & {[0.04]^{* * *}} & {[0.05]} & {[0.03]} \\ & 0.11 & 0.12 & 0.18 & -0.03 \\ & {[0.06]^{*}} & {[0.07]^{*}} & {[0.11]} & {[0.14]}\end{array}$

\section{Government Consumption}

\begin{tabular}{|c|c|c|c|c|}
\hline All Countries & $\begin{array}{r}0.15 \\
{[0.03]^{* * *}}\end{array}$ & $\begin{array}{r}-0.02 \\
{[0.08]}\end{array}$ & $\begin{array}{r}0.17 \\
{[0.04]^{* * *}}\end{array}$ & $\begin{array}{r}0.09 \\
{[0.05]^{*}}\end{array}$ \\
\hline \multirow[t]{2}{*}{ Industrial Countries } & 0.38 & -0.12 & 0.42 & 0.51 \\
\hline & {$[0.09]^{* * *}$} & {$[0.12]$} & {$[0.10]^{* * *}$} & {$[0.11]^{* * *}$} \\
\hline Developing Countries & $\begin{array}{r}0.10 \\
{[0.03]^{* * *}}\end{array}$ & $\begin{array}{r}0.11 \\
{[0.10]}\end{array}$ & $\begin{array}{r}0.10 \\
{[0.05]^{* *}}\end{array}$ & $\begin{array}{r}-0.02 \\
{[0.05]}\end{array}$ \\
\hline Emerging Markets ${ }^{2 /}$ & $\begin{array}{r}0.10 \\
{[0.09]}\end{array}$ & $\begin{array}{r}0.07 \\
{[0.14]}\end{array}$ & $\begin{array}{r}0.12 \\
{[0.08]}\end{array}$ & $\begin{array}{r}-0.11 \\
{[0.07]}\end{array}$ \\
\hline \multicolumn{5}{|l|}{ Total consumption } \\
\hline \multirow[t]{2}{*}{ All Countries } & 0.14 & -0.04 & 0.20 & 0.06 \\
\hline & {$[0.03]^{* * *}$} & {$[0.08]$} & {$[0.05]^{* * *}$} & {$[0.04]$} \\
\hline \multirow[t]{2}{*}{ Industrial Countries } & 0.39 & -0.14 & 0.47 & 0.52 \\
\hline & {$[0.10]^{* * *}$} & {$[0.11]$} & {$[0.11]^{* * *}$} & {$[0.10]^{* * *}$} \\
\hline \multirow[t]{2}{*}{ Developing Countries } & 0.08 & 0.13 & 0.04 & -0.04 \\
\hline & {$[0.04]^{* *}$} & {$[0.11]$} & {$[0.07]$} & {$[0.04]$} \\
\hline \multirow[t]{2}{*}{ Emerging Markets ${ }^{2 /}$} & 0.07 & -0.17 & 0.02 & -0.11 \\
\hline & {$[0.08]$} & {$[0.16]$} & {$[0.09]$} & {$[0.06]^{*}$} \\
\hline
\end{tabular}

Note: Standard errors are in brackets. The symbols *,**, and *** indicate statistical significance at the $10 \%, 5 \%$, and $1 \%$ level, respectively. BW, Common Shocks and Globalization, refer to the periods 19611972, 1973-1986, and 1987-2004, respectively.

${ }^{1 /}$ World aggregates are calculated using industrial-country data.

${ }^{2 /}$ Emerging Market Economies are part of the group of Developing Countries. 
Table 3. Risk Sharing -- Panel Regressions

(Yearly data)

Private Consumption

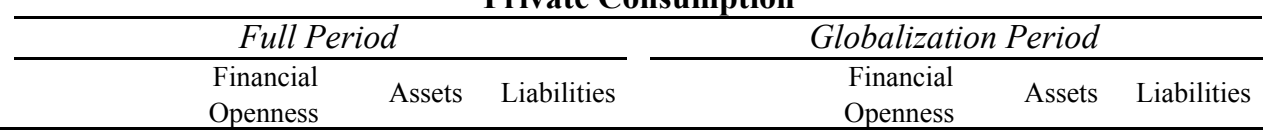

\section{All Countries}

Output
Output x Interaction ${ }^{1 /}$
R2-Adjusted
$\mathrm{N}$

\section{Industrial Countries}

Output
Output x Interaction ${ }^{1 /}$
R2-Adjusted
$\mathrm{N}$

\section{Developing Countries}

Output
Output x Interaction ${ }^{1 /}$
R2-Adjusted
N

$\begin{array}{rr}0.680 * * * & 0.737 * * * \\ {[0.034]} & {[0.036]} \\ \ldots & -0.011 \\ \ldots & {[0.015]} \\ 0.532 & 0.592 \\ 2820 & 2237\end{array}$

$0.705 * * *$
$[0.038]$

0.063

[0.064]

0.591

2232

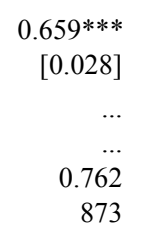

873

$$
\begin{array}{rr}
0.650 * * * & 0.641 * * * \\
{[0.037]} & {[0.040]} \\
0.000 & 0.010 \\
{[0.016]} & {[0.020]} \\
0.786 & 0.786 \\
697 & 697
\end{array}
$$

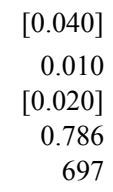

...

$0.895^{* * *}$

[0.047]

$-0.034 *$

[0.019]

0.612

0.611

1157
$0.850 * * *$
$[0.047]$
-0.030
$[0.028]$
0.608
1156

\begin{tabular}{|c|c|c|c|c|c|c|c|c|}
\hline Output & $\begin{array}{r}0.826^{* * *} \\
{[0.055]}\end{array}$ & $\begin{array}{r}0.640^{* * *} \\
{[0.088]}\end{array}$ & $\begin{array}{r}0.703 * * * \\
{[0.081]}\end{array}$ & $\begin{array}{r}0.679 * * * \\
{[0.073]}\end{array}$ & $\begin{array}{r}0.958 * * * \\
{[0.048]}\end{array}$ & $\begin{array}{r}0.847 * * * \\
{[0.097]}\end{array}$ & $\begin{array}{r}0.892 * * * \\
{[0.069]}\end{array}$ & $\begin{array}{r}0.908^{* * *} \\
{[0.094]}\end{array}$ \\
\hline Output $\mathrm{x}$ Interaction ${ }^{1 /}$ & $\begin{array}{l}\ldots \\
\ldots\end{array}$ & $\begin{array}{r}0.181^{* * *} \\
{[0.051]}\end{array}$ & $\begin{array}{r}0.396^{* * * *} \\
{[0.120]}\end{array}$ & $\begin{array}{r}0.207 * * * \\
{[0.066]}\end{array}$ & $\begin{array}{l}\ldots \\
\ldots\end{array}$ & $\begin{array}{r}0.074 \\
{[0.053]}\end{array}$ & $\begin{array}{r}0.197 \\
{[0.147]}\end{array}$ & $\begin{array}{r}0.067 \\
{[0.072]}\end{array}$ \\
\hline R2-Adjusted & 0.665 & 0.718 & 0.713 & 0.719 & 0.802 & 0.793 & 0.807 & 0.803 \\
\hline $\mathrm{N}$ & 866 & 673 & 675 & 673 & 347 & 346 & 348 & 348 \\
\hline
\end{tabular}

$0.920 * * *$

[0.053]

$-0.087^{*}$

[0.047]

0.607

1155

\section{Emerging Market Economies ${ }^{2 /}$}

Note: Robust and clustered standard errors are in brackets. The symbols *, **, and *** indicate statistical significance at the $10 \%, 5 \%$, and $1 \%$ level, respectively. Per capita consumption and output growth are deviations from their corresponding world aggregate calculated using data from industrial countries. Financial openness is measured as the ratio of gross stocks of foreign assets and liabilities to GDP. "Assets" and "Liabilities" refer to gross foreign assets and gross foreign liabilities, respectively, with both expressed as ratios to GDP. Regressions also include fixed effects and year dummies.

${ }^{1 /}$ The interaction term is the de facto financial openness measure listed in each column.

${ }^{2 /}$ Emerging Market Economies are part of the group of Developing Countries. 
Table 4. Risk Sharing -- Alternative Measures of Financial Integration. Panel Regressions (Yearly data)

\begin{tabular}{|c|c|c|c|c|c|c|c|c|c|}
\hline \multicolumn{5}{|c|}{ Full Period } & \multicolumn{5}{|c|}{ Globalization Period } \\
\hline FDI & Equity & Debt & $\begin{array}{l}\text { FDI + } \\
\text { Equity }\end{array}$ & $\begin{array}{l}\text { FDI + } \\
\text { Equity }\end{array}$ & FDI & Equity & Debt & $\begin{array}{l}\text { FDI + } \\
\text { Equity }\end{array}$ & $\begin{array}{l}\text { FDI + } \\
\text { Equity }\end{array}$ \\
\hline
\end{tabular}

\section{All Countries}

\begin{tabular}{|c|c|c|c|c|c|c|c|c|c|c|}
\hline Output & $\begin{array}{r}0.740 * * * \\
{[0.041]}\end{array}$ & $\begin{array}{r}0.722 * * * \\
{[0.035]}\end{array}$ & $\begin{array}{r}0.736^{* * * *} \\
{[0.035]}\end{array}$ & $\begin{array}{r}0.733 * * * \\
{[0.038]}\end{array}$ & $\begin{array}{r}0.730 * * * \\
{[0.038]}\end{array}$ & $\begin{array}{r}0.966^{* * * *} \\
{[0.053]}\end{array}$ & $\begin{array}{r}0.852 * * * \\
{[0.044]}\end{array}$ & $\begin{array}{r}0.879^{* * * *} \\
{[0.045]}\end{array}$ & $\begin{array}{r}0.888 * * * \\
{[0.051]}\end{array}$ & $\begin{array}{r}0.871^{* * *} * \\
{[0.047]}\end{array}$ \\
\hline Output $\mathrm{x}$ Interaction ${ }^{1 /}$ & $\begin{array}{r}-0.098 \\
{[0.096]}\end{array}$ & $\begin{array}{r}-0.042 \\
{[0.036]}\end{array}$ & $\begin{array}{r}-0.016 \\
{[0.019]}\end{array}$ & $\begin{array}{r}-0.048 \\
{[0.043]}\end{array}$ & $\begin{array}{c}-0.002 \\
{[0.051]}\end{array}$ & $\begin{array}{r}-0.529 * * * \\
{[0.117]}\end{array}$ & $\begin{array}{l}-0.110^{*} \\
{[0.059]}\end{array}$ & $\begin{array}{r}-0.041 \\
{[0.032]}\end{array}$ & $\begin{array}{c}-0.117^{*} \\
{[0.059]}\end{array}$ & $\begin{array}{c}-0.138^{*} \\
{[0.074]}\end{array}$ \\
\hline Output x Debt & $\begin{array}{l}\ldots \\
\ldots\end{array}$ & $\begin{array}{l}\ldots \\
\ldots\end{array}$ & $\begin{array}{l}\ldots \\
\ldots\end{array}$ & $\begin{array}{l}\ldots \\
\ldots\end{array}$ & $\begin{array}{r}-0.013 \\
{[0.023]}\end{array}$ & $\begin{array}{l}\cdots \\
\ldots\end{array}$ & $\begin{array}{l}\ldots \\
\ldots\end{array}$ & $\begin{array}{l}\ldots \\
\ldots\end{array}$ & 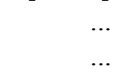 & $\begin{array}{r}0.022 \\
{[0.047]}\end{array}$ \\
\hline R2-Adjusted & 0.579 & 0.578 & 0.587 & 0.577 & 0.575 & 0.621 & 0.612 & 0.605 & 0.621 & 0.61 \\
\hline $\mathrm{N}$ & 2243 & 2247 & 2243 & 2245 & 2243 & 1160 & 1157 & 1155 & 1159 & 11 \\
\hline
\end{tabular}

\section{Industrial Countries}

Output
Output $x$ Interaction
Output $x$ Debt
R2-Adjusted
N

$\begin{array}{rrrrr}0.636 * * * & 0.650 * * * & 0.644 * * * & 0.648 * * * & 0.620 * * * \\ {[0.042]} & {[0.036]} & {[0.039]} & {[0.038]} & {[0.037]} \\ 0.043 & -0.022 & 0.005 & -0.005 & -0.117 \\ {[0.104]} & {[0.023]} & {[0.014]} & {[0.022]} & {[0.083]} \\ \ldots & \ldots & \ldots & \ldots & 0.068 \\ \ldots & \ldots & \ldots & \ldots & {[0.047]} \\ 0.782 & 0.782 & 0.786 & 0.782 & 0.772 \\ 699 & 699 & 697 & 699 & 697\end{array}$

$\begin{array}{rrrrr}0.702 * * * & 0.695 * * * & 0.705^{* * *} & 0.706 * * * & 0.700 * * * \\ {[0.036]} & {[0.027]} & {[0.031]} & {[0.028]} & {[0.038]} \\ -0.101 & -0.085 * * * & -0.023 * * & -0.057 * * * & -0.164 * \\ {[0.093]} & {[0.021]} & {[0.010]} & {[0.016]} & {[0.094]} \\ \ldots & \ldots & \ldots & \ldots & 0.058 \\ \ldots & \ldots & \ldots & \ldots & {[0.055]} \\ 0.617 & 0.620 & 0.618 & 0.619 & 0.621 \\ 358 & 359 & 358 & 359 & 359\end{array}$

\section{Developing Countries}

Output
Output x Interaction ${ }^{1 /}$
Output x Debt
R2-Adjusted
$\mathrm{N}$

$$
\begin{array}{rrrrr}
0.741 * * * & 0.710^{* * *} & 0.732 * * * & 0.702 * * * & 0.716^{* * *} \\
{[0.048]} & {[0.040]} & {[0.039]} & {[0.050]} & {[0.053]} \\
-0.155 & 1.404 * & -0.002 & 0.126 & 0.094 \\
{[0.109]} & {[0.824]} & {[0.028]} & {[0.094]} & {[0.096]} \\
\ldots & \ldots & \ldots & \ldots & -0.010 \\
\ldots & \ldots & \ldots & \ldots & {[0.027]} \\
0.536 & 0.552 & 0.550 & 0.555 & 0.547 \\
1553 & 1555 & 1547 & 1552 & 1549
\end{array}
$$

\begin{tabular}{|c|c|c|c|c|c|c|c|c|c|c|}
\hline Output & $\begin{array}{r}0.730 * * * \\
{[0.063]}\end{array}$ & $\begin{array}{r}0.825 * * * \\
{[0.056]}\end{array}$ & $\begin{array}{r}0.683 * * * \\
{[0.072]}\end{array}$ & $\begin{array}{r}0.762 * * * \\
{[0.065]}\end{array}$ & $\begin{array}{r}0.650 * * * \\
{[0.083]}\end{array}$ & $\begin{array}{r}0.910 * * * \\
{[0.071]}\end{array}$ & $\begin{array}{r}0.989 * * * \\
{[0.053]}\end{array}$ & $\begin{array}{r}0.894 * * * \\
{[0.083]}\end{array}$ & $\begin{array}{r}0.935 * * * \\
{[0.072]}\end{array}$ & $\begin{array}{r}0.812 * * * \\
{[0.080]}\end{array}$ \\
\hline Output $\mathrm{x}$ Interaction $^{1 /}$ & $\begin{array}{r}0.719 * * * \\
{[0.210]}\end{array}$ & $\begin{array}{r}0.699 \\
{[0.839]}\end{array}$ & $\begin{array}{r}0.182 * * * \\
{[0.050]}\end{array}$ & $\begin{array}{c}0.390^{*} \\
{[0.219]}\end{array}$ & $\begin{array}{r}0.274 \\
{[0.191]}\end{array}$ & $\begin{array}{r}0.177 \\
{[0.277]}\end{array}$ & $\begin{array}{r}-0.505 \\
{[0.670]}\end{array}$ & $\begin{array}{r}0.077 \\
{[0.052]}\end{array}$ & $\begin{array}{r}0.078 \\
{[0.232]}\end{array}$ & $\begin{array}{r}0.078 \\
{[0.194]}\end{array}$ \\
\hline Output x Debt & $\begin{array}{l}\ldots \\
\ldots\end{array}$ & $\ldots$ & $\ldots$ & $\begin{array}{l}\ldots \\
\ldots\end{array}$ & $\begin{array}{r}0.171^{* * * *} \\
{[0.048]}\end{array}$ & $\begin{array}{l}\ldots \\
\ldots\end{array}$ & $\begin{array}{l}\ldots \\
\ldots\end{array}$ & $\begin{array}{l}\ldots \\
\ldots\end{array}$ & $\begin{array}{l}\ldots \\
\ldots\end{array}$ & $\begin{array}{r}0.122 * * * \\
{[0.042]}\end{array}$ \\
\hline R2-Adjusted & 0.715 & 0.717 & 0.715 & 0.713 & 0.718 & 0.783 & 0.803 & 0.804 & 0.785 & 0.788 \\
\hline $\mathrm{N}$ & 672 & 675 & 674 & 673 & 673 & 346 & 348 & 348 & 347 & 34 \\
\hline
\end{tabular}

$$
\begin{array}{rrrrr}
0.977 * * * & 0.867 * * * & 0.872 * * * & 0.983 * * * & 1.030^{* * *} \\
{[0.060]} & {[0.053]} & {[0.065]} & {[0.062]} & {[0.086]} \\
-0.532 * * * & -0.105 & 0.004 & -0.514 * * * & -0.590 * * * \\
{[0.138]} & {[0.948]} & {[0.079]} & {[0.151]} & {[0.128]} \\
\ldots & \ldots & \ldots & \ldots & -0.022 \\
\ldots & \ldots & \ldots & \ldots & {[0.065]} \\
0.588 & 0.586 & 0.589 & 0.587 & 0.600 \\
801 & 800 & 796 & 801 & 798
\end{array}
$$

\section{Emerging Market Economies ${ }^{2 /}$}

Note: Robust and clustered standard errors are in brackets. The symbols *, $* *$, and $* * *$ indicate statistical significance at the $10 \%, 5 \%$, and $1 \%$ level, respectively. Per capita consumption and output growth are deviations from their corresponding world aggregate calculated using data from industrial countries. Regressions also include fixed effects and year dummies.

${ }^{1 /}$ The interaction term is the de facto financial openness measure listed in each column.

${ }^{2 /}$ Emerging Market Economies are part of the group of Developing Countries. 


\section{Table 5. Country Characteristics and Risk Sharing}

(Yearly data)

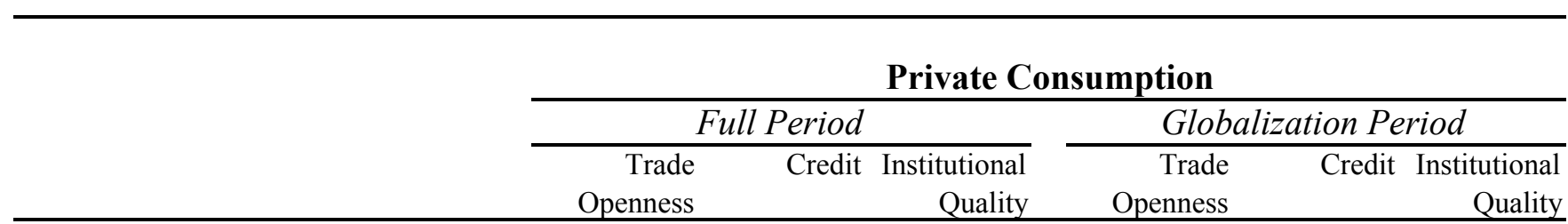

\section{All Countries}

Output
Output x Interaction ${ }^{1 /}$
R2-Adjusted
$\mathrm{N}$
II. Industrial Countries

Output

Output $\mathrm{x}$ Interaction ${ }^{1 /}$

R2-Adjusted

$\mathrm{N}$

\section{Developing Countries}

$0.752 * * *$

[0.048]

$-0.112 * *$

[0.053]

0.503

1947

$$
\begin{array}{rr}
0.675^{* * *} & 0.655^{* * *} \\
{[0.063]} & {[0.049]} \\
0.034 & 0.115^{* *} \\
{[0.062]} & {[0.053]} \\
0.504 & 0.522 \\
1700 & 1881
\end{array}
$$
$0.650 * * *$
[0.043]
$0.078^{*}$
[0.043]
0.544
2727
$0.972 * * *$
[0.039]
$-0.351 * * *$
[0.065]
0.615
1155

$0.814^{* * *}$

[0.054]

0.068

[0.067]

0.603

1157
$0.857^{* * *}$

[0.054]

$-0.064$

[0.070]

0.598

1123

$\mathrm{N}$$$
0.979 * * *
$$$$
0.866^{* * *}
$$$$
\text { [0.064] }
$$$$
\text { [0.045] }
$$

$-0.246 * * *$

0.012

[0.078]

[0.069]

0.589

795

$0.619 * * *$
$[0.046]$
0.070
$[0.065]$
0.604
358

$0.608^{* * *}$

[0.034]

0.087

[0.052]

0.613

355

\section{Emerging Market Economies ${ }^{2 /}$}
Output
Output $\mathrm{x}$ Interaction ${ }^{1 /}$
R2-Adjusted
$\mathrm{N}$
$0.824^{* * *}$
[0.059]
0.000
[0.069]

$0.854^{* * *}$

$0.801 * * *$

$0.969^{* * *}$

$0.948^{* * *}$

$0.974 * * *$

[0.069]

[0.078]

[0.060]

[0.056]

[0.057]

0.010

0.055

$-0.030$

0.015

$-0.037$

[0.075]

0.708

863

[0.086]

[0.076]

0.793

[0.083]

0.796

866

$0.876^{* * *}$

[0.060]

$-0.029$

[0.081]

0.587

766

\footnotetext{
Note: Robust and clustered standard errors are in brackets. The symbols *, ${ }^{* *}$, and ${ }^{* * *}$ indicate statistical significance at the $10 \%, 5 \%$, and $1 \%$ level, respectively. Per capita consumption and output growth are deviations from their corresponding world aggregate calculated using data from industrial countries. Regressions also include fixed effects and year dummies.

${ }^{1 /}$ The interaction term is the country characteristic listed in each column.

${ }^{2 /}$ Emerging Market Economies are part of the group of Developing Countries.
} 

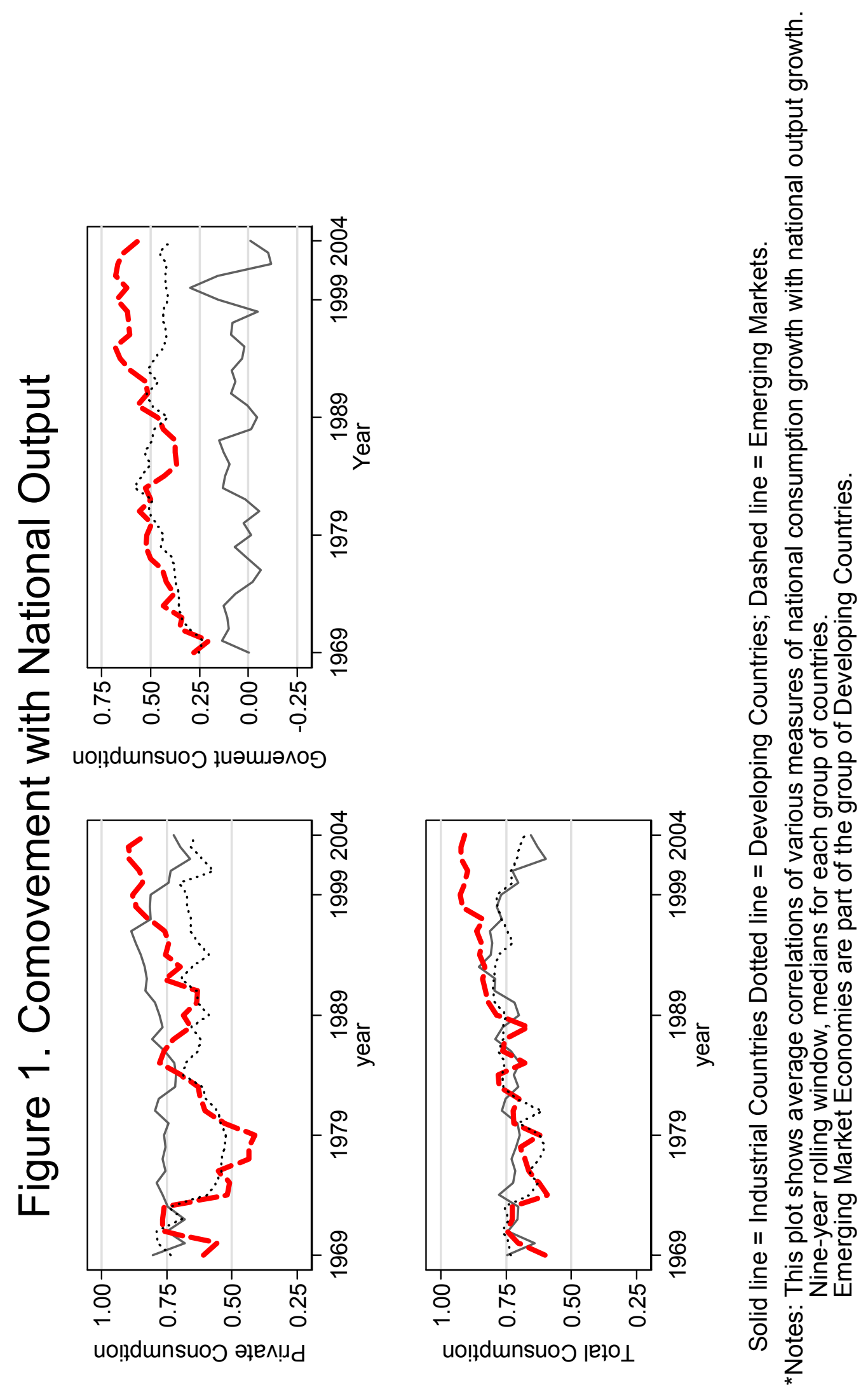


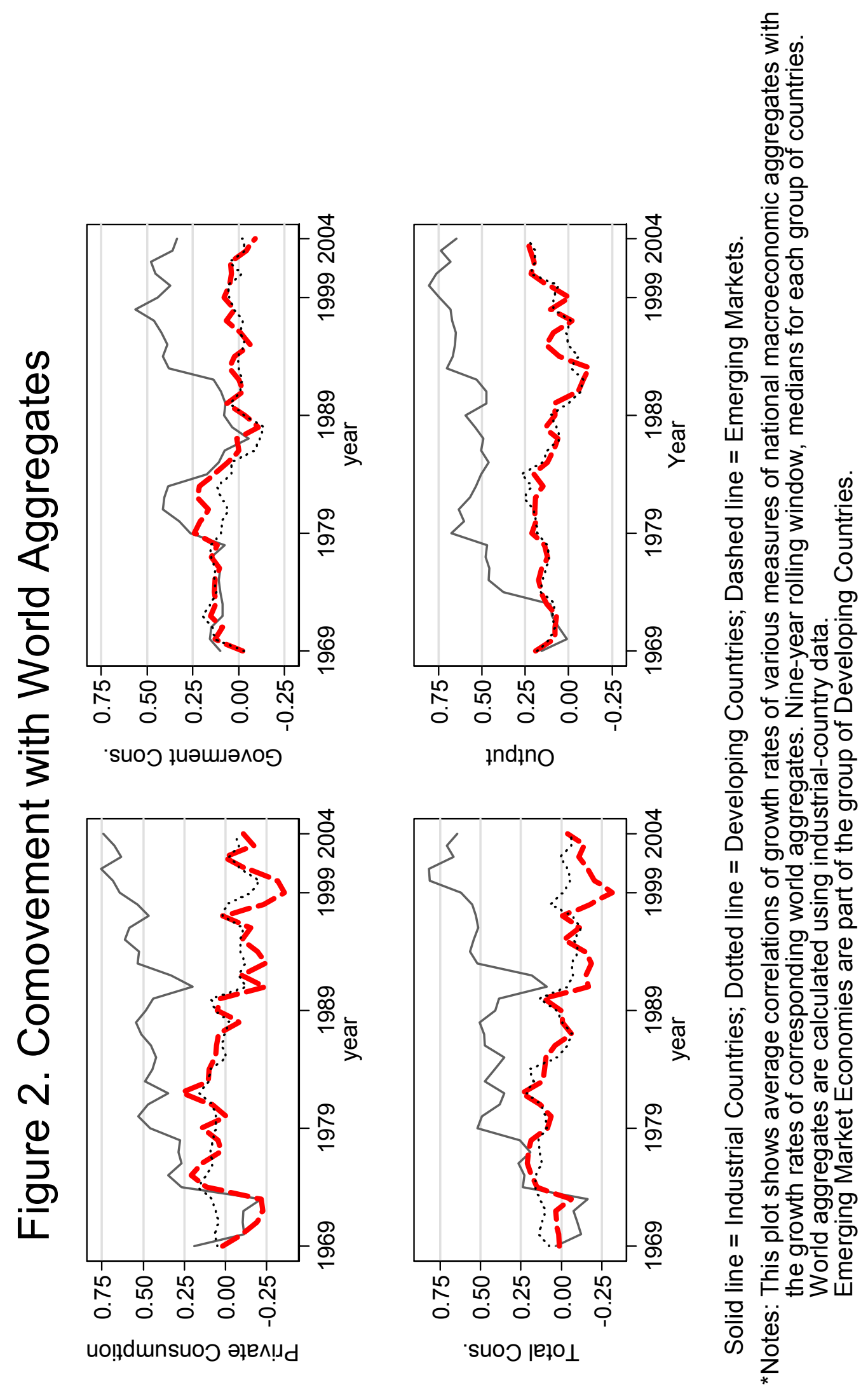



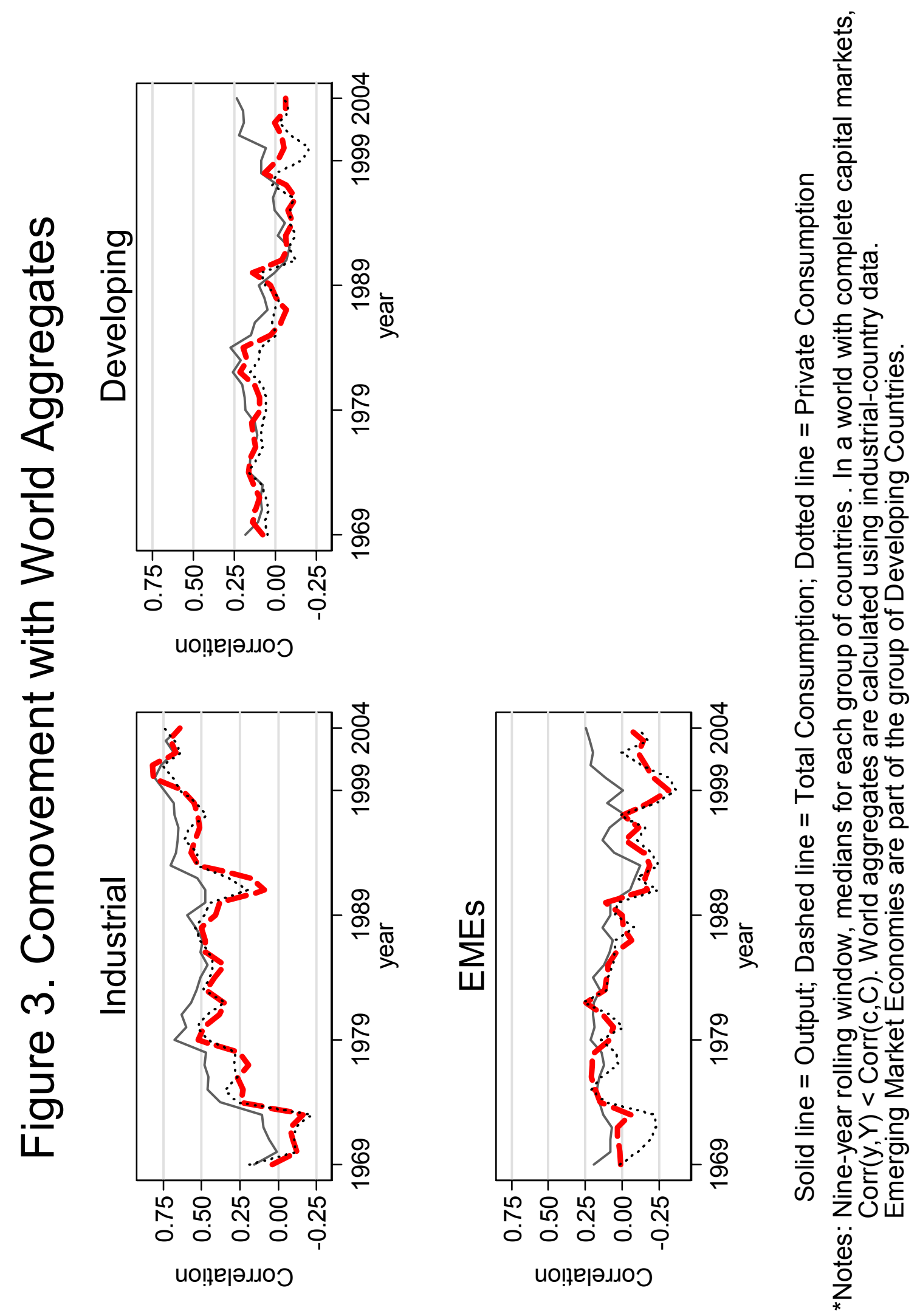

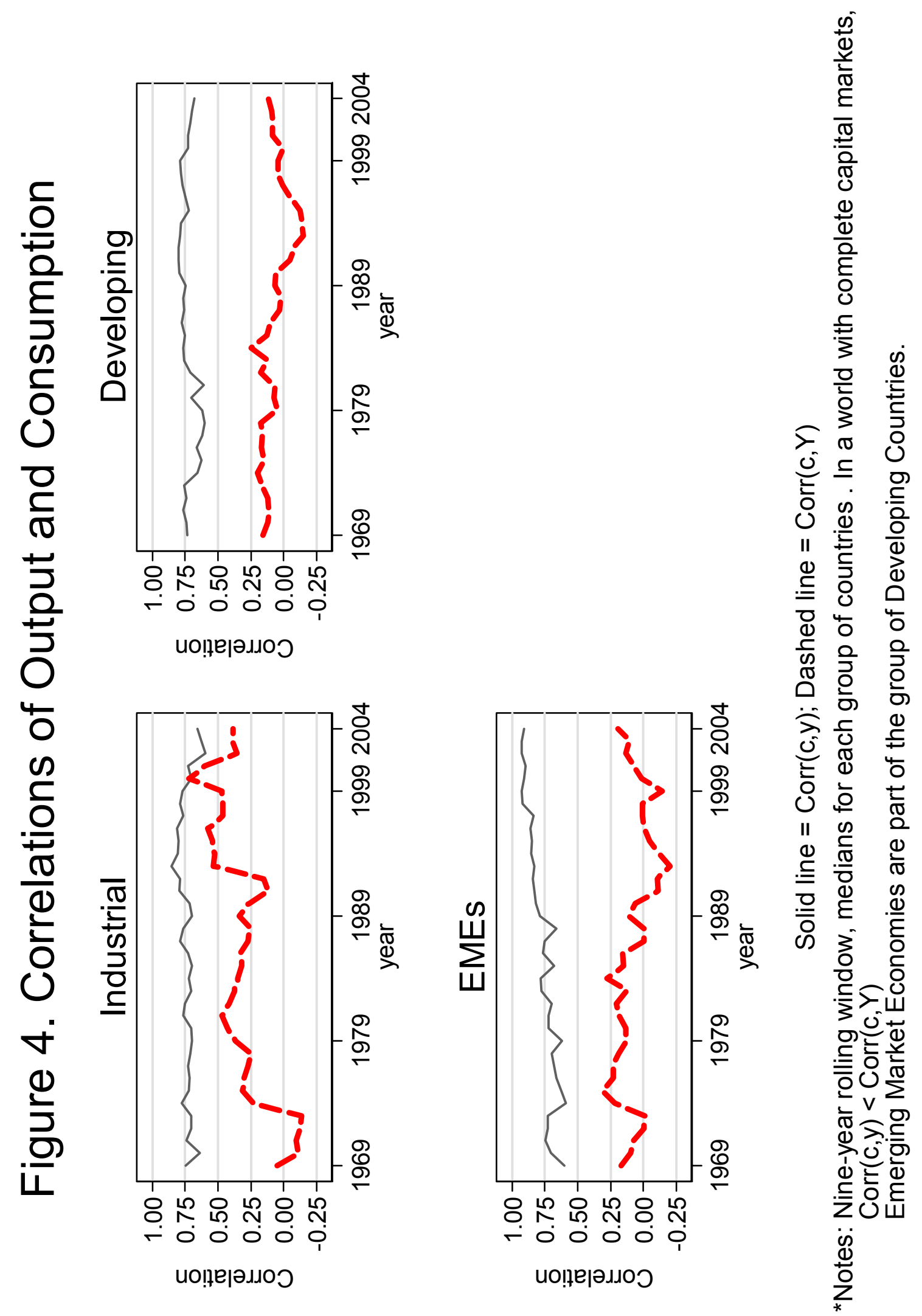

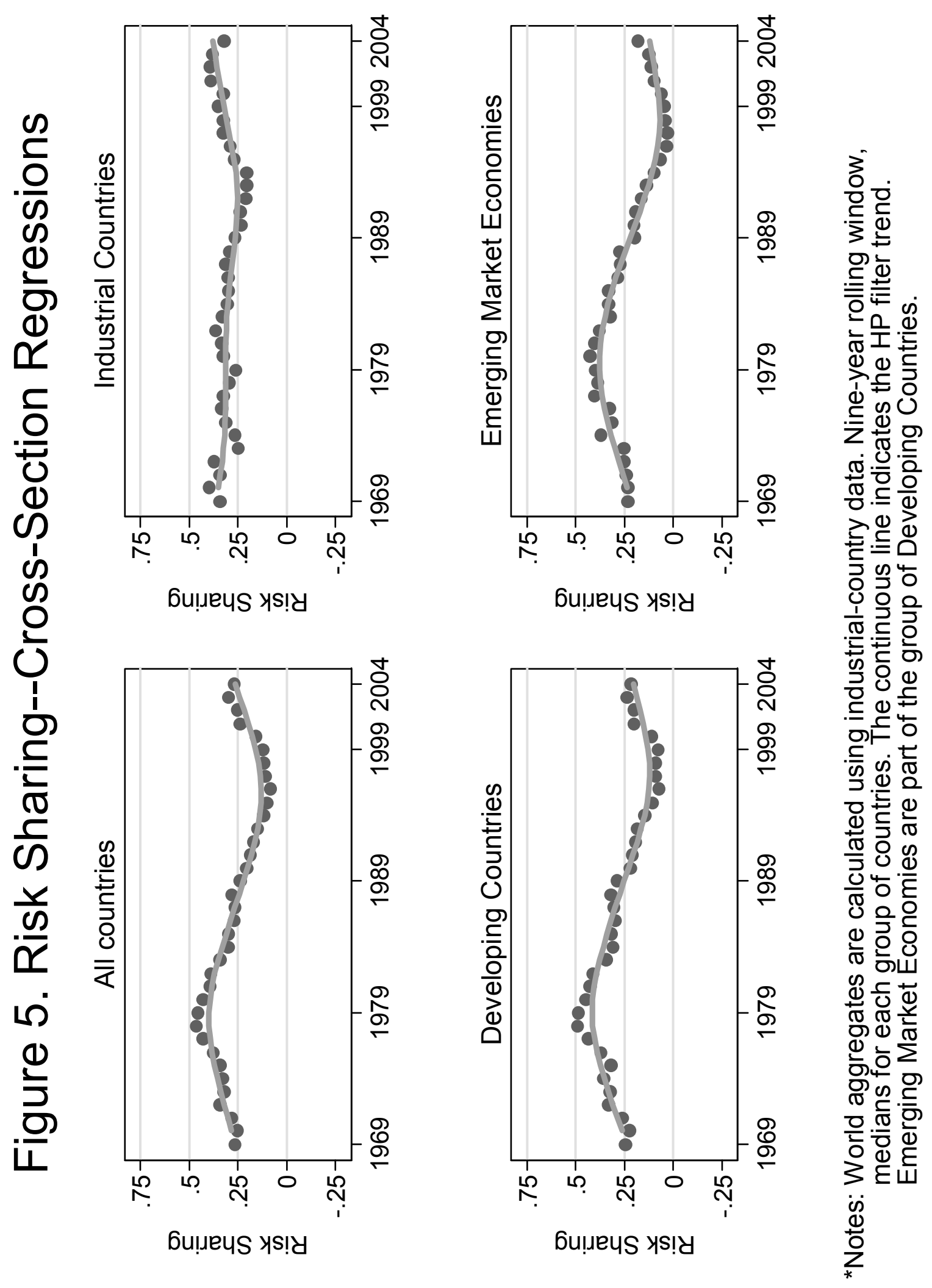


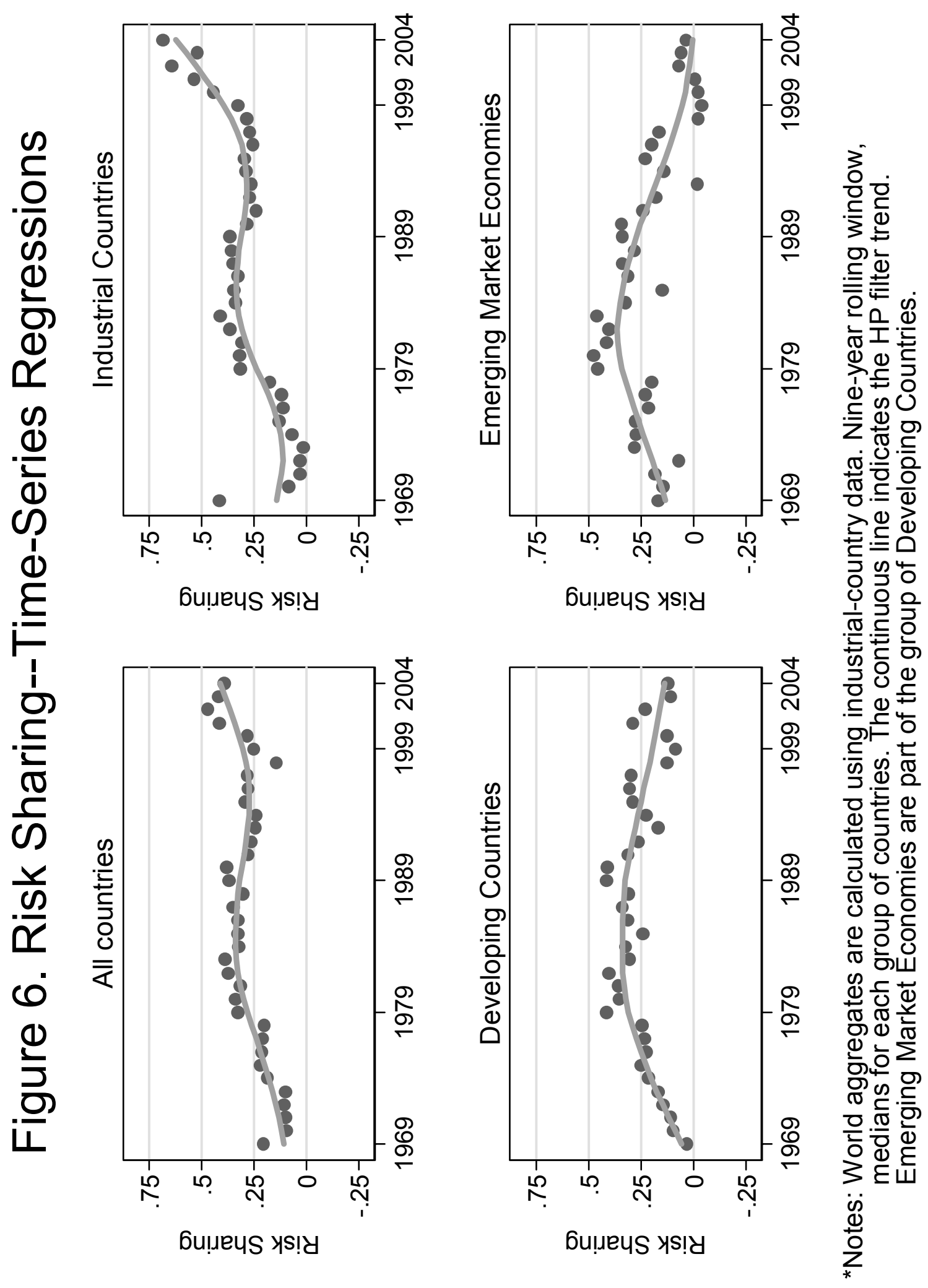




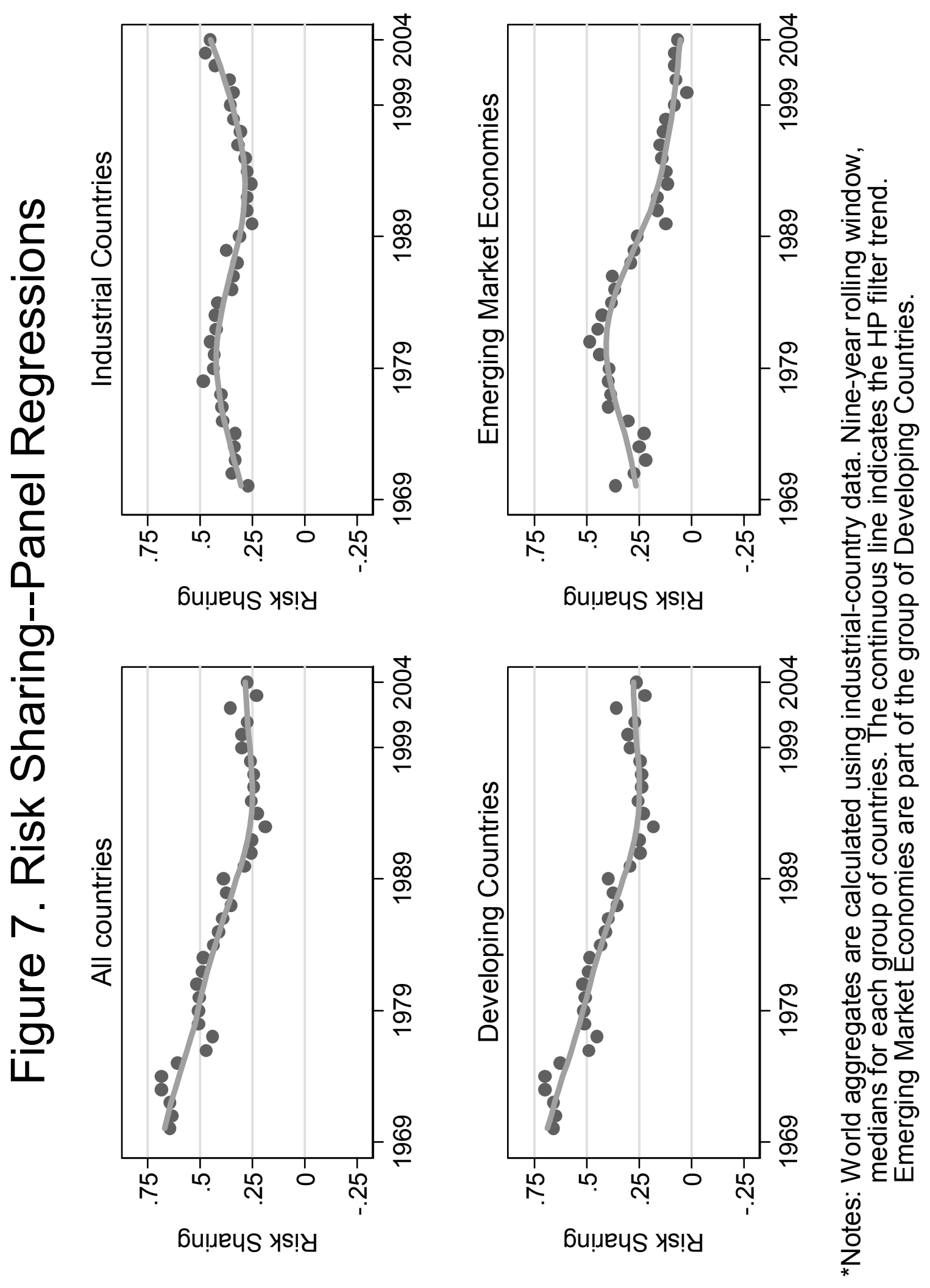




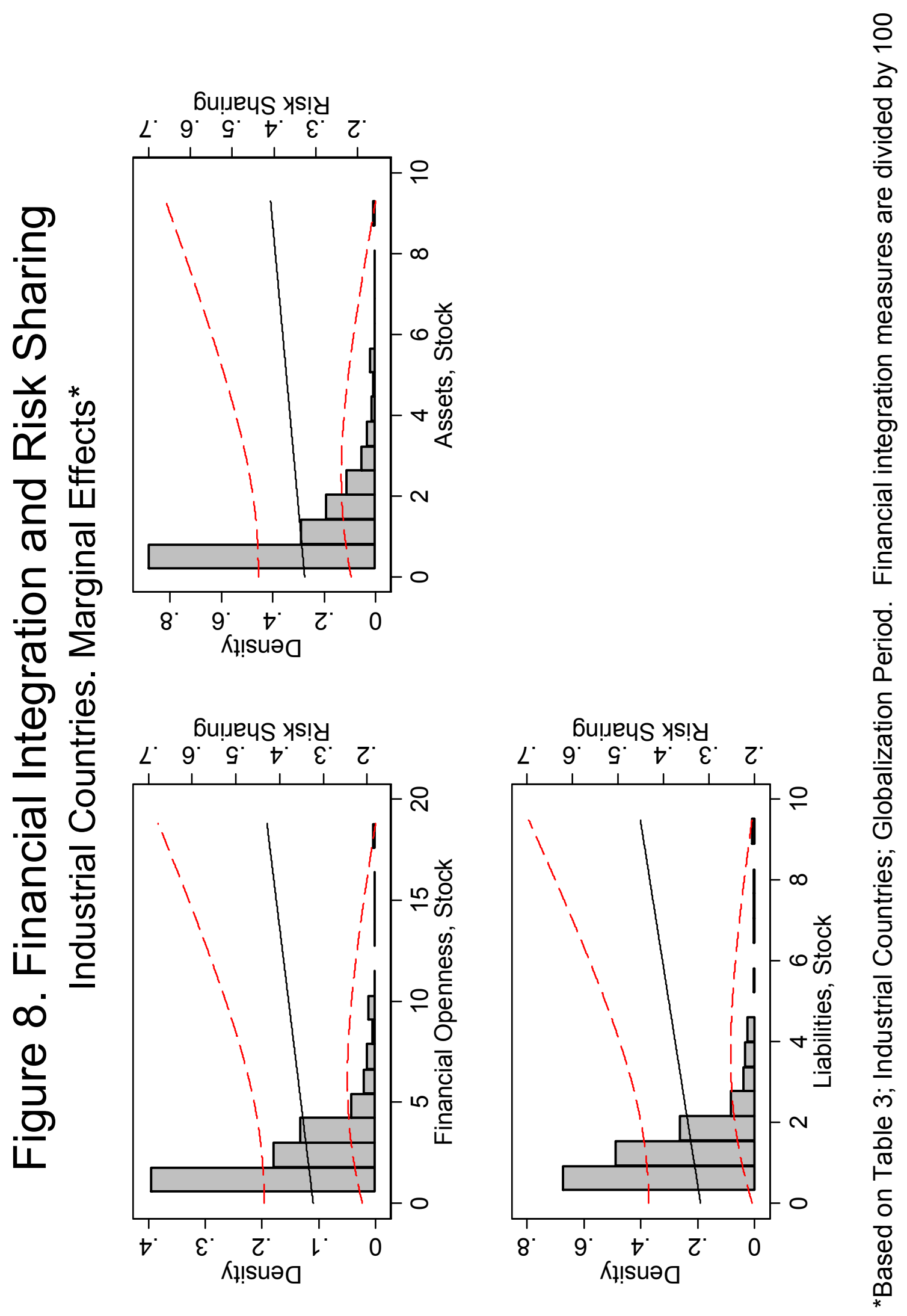

